\title{
Pedagogia da ação prática na empresa
}

\author{
Ivo Canisio Mallmann
}

Resumo: O presente trabalho relaciona a ação experimental de educação e responsabilização em processo inicial, na empresa ICM Obras e Serviços de Engenharia Ltda., com a impostação de uma díade evolutiva nas relações de trabalho. Esta intervenção na empresa possui o objetivo de humanizar, construir premissas e oportunidades de desenvolvimento pessoal para os profissionais através do constante questionamento das possibilidades de evolução e autonomia. Busca acessar a forma mentis de cada profissional e construir uma nova relação de valor do indivíduo com seu trabalho, com o valor social do trabalho, contribuindo na evolução pessoal, nos aspectos de conhecimento, ganho econômico e realização integral como ser humano. O modo de operar na empresa agrega valor através do uso de equipamentos que facilitam e qualificam a execução das obras com uma redução substancial do esforço humano e que também requer uma equipe mais responsável e qualificada. Faz uma análise das atuais circunstâncias da legislação trabalhista e aponta para ações que possam elevar o nível de liberdade de atuação dos profissionais pertencentes à empresa, especialmente com o objetivo de desenvolver de forma integral a capacidade do ser humano e fomentar a meritocracia.

Palavras-chave: Ação Prática; Empresa; Meritocracia; Pedagogia Ontopsicológica.

\section{Pedagogy of practical action in the company}

Abstract: The present work relates the experimental action of education and accountability, in the beginning of the process, in the company "ICM Obras e Serviços de Engenharia Ltda.", with the setting of an evolving dyad in the working relations. This intervention at the company aims to humanize and create premises and opportunities for personal development for the workers through the constant questioning of the possibilities of evolving and autonomy. It seeks to access the forma mentis of each professional and builds a new relation of value of the individual with his work, with the social value of work, contributing in personal evolution, in knowledge aspects, economic gain and integral achievement as human being. The way of operation in the company adds value through the use of equipments that qualifies the executions of the building and makes them easier, with a substantial reduction of the human effort, which also demands a more responsible and qualified team. We make a analysis of today's working laws circumstances and points to actions that can elevate the level of freedom of action for the professionals that work in the company, especially with the objective of wholly develop the capacity of the human being and promote meritocracy.

Keywords: Practical Action; Company; Meritocracy; Ontopsychological Pedagogy.

Pedagogía de la acción práctica en la empresa 
Resumen: El presente trabajo relaciona la acción experimental de educación y responsabilidad en el proceso inicial, en la empresa ICM Obras y Servicios de Ingeniería Ltda., con la imposición de una díada evolutiva en las relaciones de trabajo. Esta intervención en la empresa tiene el objetivo de humanizar, construir premisas y oportunidades de desarrollo personal para los profesionales a través del constante cuestionamiento de las posibilidades de evolución y autonomía. Busca acceder la forma mentis de cada profesional y construir una nueva relación de valor del individuo con su trabajo, con el valor social del trabajo, contribuyendo en la evolución personal, en los aspectos del conocimiento, avanzo económico y realización integral como ser humano. El modo de operar en la empresa agrega valor a través del uso de instrumentos que facilitan y califican la ejecución de las obras con una reducción sustancial del esfuerzo humano y que también requiere un equipo más responsable y calificado. Hace un análisis de las actuales circunstancias de la legislación laboral y apunta para acciones que puedan elevar el nivel de libertad de actuación de los profesionales pertenecientes a la empresa, especialmente con el objetivo de desarrollar de forma integral la capacidad del ser humano y fomentar la meritocracia.

Palabras clave: Acción Práctica; Empresa; Meritocracia; Pedagogía Ontopsicológica.

\section{Introdução}

Este trabalho possui como tema a pedagogia de ação prática de responsabilidade e reciprocidade, presente na ICM Obras e Serviços de Engenharia Ltda., com o objetivo de promover uma evolução dos valores de justiça, dignidade apontando resultados positivos aos profissionais que nela trabalham.

A empresa atua na atividade da construção civil e locação de máquinas pesadas para construção. Iniciou suas atividades em abril de 2000 tendo sede na cidade de Nova Palma situando hoje seu parque de máquinas e equipamentos à rodovia RS149, próximo ao Distrito Recanto Maestro. No momento possui um grupo de vinte e um profissionais.

O grupo destaca-se na construção de prédios comerciais, centros de saúde, educação e cultura e residências com características muito especiais. Sua caracterização e atuação são marcadas pela criatividade do empreendedor, diferencial que permite oferecer soluções tecnológicas de maior valor, com ganho competitivo e sustento do processo evolutivo da organização.

O título do presente trabalho é: pedagogia da ação na empresa. O título liga-se ao tema que perpassa o desenvolvimento intelectual e prático na relação entre empresa e colaboradores. As inter-relações no grupo de profissionais que nela trabalham foram estimuladas a partir do conhecimento que seu proprietário obteve como aluno do MBA 
Business Intuition Identidade Empresarial, especialização lato sensu na área administração e neste momento cursando o Bacharelado em Ontopsicologia pela Antonio Meneghetti Faculdade.

O estudo da Psicologia do Líder e da Psicologia Empresarial foi base para o desenvolvimento do curso de MBA, constando também no Bacharelado em Ontopsicologia, onde é motivação para apostar na relação de valor das pessoas com a empresa. $\mathrm{O}$ aprofundamento do estudo para compreensão do ser humano, motiva o gestor da Empresa a desenvolver ações práticas que contribuam no desenvolvimento intelectual e humano de si mesmo e dos seus colaboradores, com projeção de resultado econômico e protagonismo para uma sociedade futura melhor.

A Pedagogia Ontopsicológica orienta que "não se deve dar por misericórdia", porque isso é tornar-se cúmplice do débito dos outros. Ou seja, a meritocracia deve ser um método importante. Meneghetti ensina que:

“(...) dar o peixe sem ensinar a pescar é um assassínio da evolução do homem, da educação e do processo de responsabilização. Enquanto prestamos assistencialismo ao homem o mantemos inferior e dependente, impedindo a própria realização" (MENEGHETTI, 2008, p. 128).

O objetivo geral deste trabalho é descrever o modo de relação na ICM Obras com o propósito de construir um novo conceito de responsabilidade e reciprocidade da empresa com os profissionais que nela trabalham e destes entre si.

O trabalho justifica-se como relevância social e científica por abrir caminho para um novo modelo de relação onde a premissa é o dever de fazer o próprio crescimento a partir das possibilidades e oportunidades que o colaborador pode encontrar na empresa desenvolvendo seu trabalho, não se limitando a exercer uma função pré-estabelecida. Esta é uma lógica fundamental para o desenvolvimento do processo de pedagogia dentro da empresa e com as pessoas que compõem a empresa. Dentro de um critério de oportunidades, o profissional é incentivado a desenvolver habilidades além da sua função, o que pode se tornar promoções e melhorias de salário. Por exemplo, o treinamento na operação de serra circular para serventes de obra, além de servir pontualmente a uma necessidade da empresa, o torna apto para aprender o oficio de carpinteiro. Também o treinamento em altura é feito para todos, criando um leque de oportunidades de trabalhos extrafunção propiciando inúmeros conhecimentos. 


\section{Fundamentação Teórica}

Realizar um novo modelo de relações na empresa requer planejamento, treinamento e permanente trabalho de conscientização com todas as pessoas que integram a empresa, abrangendo todo o quadro funcional a partir do gestor, que deve ser o exemplo mais forte na crença do ganho de valor com tal proposta, incentivando o "empoderamento" e o protagonismo como valores para os profissionais.

Estas ações exigem uma nova atitude, que supera as leis e burocracias estabelecidas, trata-se de olhar além. É importante salientarmos que:

Sejam os policiais, sejam os juízes e todo o vasto canal de burocracia por meio do qual se exercita o corpo físico do Estado, são, substancialmente, pessoas frustradas nas próprias vidas e, tendo a sua frente o cidadão vencedor, é impossível que sejam justos. Neles é muito forte a revanche psicológica (MENEGHETTI, 2008, p. 115).

Toda mudança de paradigma ou inovação traz novidades e transgressão ao status quo e que facilmente pode ativar esta revanche.

O trabalhador brasileiro, de modo geral habituou-se a um modo de pensamento e postura onde espera todo o tipo de generosidade por parte da empresa como: alimentação, transporte, moradia, saúde, equipamentos, o melhor salário possível pelo menor esforço, perdendo assim a noção de dever, além dos direitos, isso resulta na perca da autonomia. Aceitar assistencialismo é um tipo de infantilismo disfarçado. Qual a causa de tudo isto? "Quanto mais os outros me assistem tanto mais aumenta a minha mediocridade interior" (MENEGHETTI, 2011, p. 62).

O Ministro da Educação José Mendonça Bezerra Filho, em entrevista coletiva afirmou que o Estado vê com preocupação uma massa de mais de 1,7 milhões de jovens entre 18 e 24 anos de idade que não trabalham e não estudam. Pessoas que são totalmente assistidas, comem, vestem roupas, moram em alguma casa, fazem sexo, usam as estruturas de transporte, recreação, vivendo uma vida sem sentido. Por outro lado, nas organizações, faltam pessoas habilitadas para todo tipo de trabalho. O jovem tem dentro de si a informação de que trabalhar e estudar é um sacrifício, trata-se de um estereótipo, negativo em sua estrutura.

Ensinar a autorresponsabilização tem sido desafiador, trata-se na maioria das vezes de formar pessoas que durante toda a vida não foram autônomas. Trabalham por obrigação, não como participantes de um processo que gera autonomia e realização. 
Existe hoje um assistencialismo excessivo que substitui aquele sacrifício natural que cada um deve aprender na vida. Além disso, "é preciso considerar que a sociedade atual é muito pesada, tudo está sob a lei e não existe mais uma vida privada como havia uma vez" (MENEGHETTI, 2013, p. 66).

$\mathrm{Na}$ construção civil existem muitas vagas de trabalho, mas é preciso ensinar tudo, não há o mínimo de instrução. Diariamente, candidatos procuram trabalho, mas nunca trabalharam e não sabem fazer nada. Apresentam-se de modo inadequado no vestir, nos acessórios e muitas vezes com sequelas de danos causados pelo uso do álcool e outras formas de droga.

Outro exemplo nos dias atuais é o modo como a lei trabalhista se desenvolve. Geralmente evidenciando mais uma relação de direitos do que de deveres. Por exemplo, a insalubridade que os sindicatos alegam que deve ser paga ao trabalhador da construção civil, mas por meio do INSS a empresa é processada por antecipar a aposentadoria do trabalhador caso pague insalubridade. Igualmente o Ministério do Trabalho pune severamente a empresa que permite que seu trabalhador faça jornada maior que dez horas ao dia, mesmo que cumpra toda a legislação pertinente ao pagamento do adicional de horas trabalhadas, fazendo com que todos se igualem e não possa haver melhor resultado pessoal por maior esforço de trabalho. O Estado, como um todo, está preocupado em criar uma legislação "inclusiva" para que mais pessoas tenham acesso ao trabalho, como uma espécie de "caridade", mesmo que isto não represente vitalidade e solução de valor para o trabalhador. A competição e competitividade são vistos pelo Estado como fatores negativos e a meritocracia assim fica impedida.

É preciso cautela e criação de mecanismos que garantam segurança jurídica, construída através de acordos de valor entre empregados e empregadores e chancelados por entidade com poder legal para tanto (sindicatos, promotorias públicas, etc.).

Na ICM Obras tem um processo, em que as primeiras iniciativas começam a ser testadas e necessitam de formalização e fundamentação em preceitos que garantam a proteção legal. As ações e modelo de empresa precisam ser formatadas fora do quadrado formal de praxe, isso exige muito trabalho e criatividade. Precisa moldar novos instrumentos de aferição para desenvolver um modelo que contemple os que são capazes de fazer melhor e o melhor, respeitando evidentemente os limites e escolhas de cada um de modo a não transformar o conceito de meritocracia em uma guerra interna na Empresa, ou seja, em nossa concepção, meritocracia e humanismo são complementares. Infelizmente 
isto ainda não é relevante às instituições governamentais e sindicatos, que visam mais pessoas pagando contribuições mensais e aquelas querem contabilizar maior número de carteiras de trabalho assinadas.

Existem algumas organizações que conseguiram instituir ações úteis e funcionais para a empresa e para os empregados com esta nova visão. Por exemplo, a Fábrica de Móveis Marelli na cidade de Caxias do Sul-RS, já tem implantado com excelentes resultados para o trabalhador, um modelo que através do Plano de Participação de Resultados (PPR), consegue fazer com que durante o ano o profissional possa, através de seu esforço, receber o equivalente a 18 salários. Também o modelo da Fábrica de Calçados Beira Rio S/A, através do Programa Conquistando a Perfeição desenvolve conceitos de valorização através daquilo que “cada um sabe fazer melhor”. Os critérios de merecimento são meta permanente.

As empresas buscam atender normas ISO (Organização Internacional para Padronização) e que olham para qualidade dos produtos, resultado econômico e muito pouco para o ser humano e, quando olham, o fazem com o objetivo de proteção e assistencialismo. Na visão da maioria das instituições, que estabelecem regras e fiscalizam o trabalho, as empresas ainda são vistas como exploradoras e não como portadoras de oportunidades de crescimento econômico e social para todos. Não que se deva neutralizar a ação reguladora e fiscalizadora, mas também estes órgãos precisam abrir espaço para uma nova pedagogia humanista do trabalho. Ou seja, trata-se de perceber as empresas com uma visão otimista, que acreditam no ser humano capaz e autônomo, reduzindo a tutela do Estado a um processo de vigilância. Por hora, não existe um programa facilitador para um novo paradigma e uma legislação que o incentive. Faltam pessoas preparadas e capazes que possam promover estas ações.

Esta nova mentalidade e modo de proceder, que incentiva ações com visão mais humanista deve ter início no processo de educação, ou seja, em escolas e instituições de ensino, como a Antonio Meneghetti Faculdade, que acreditam no ser humano autônomo e capaz.

\section{Método}

Como metodologia de pesquisa o estudo possui um formato de pesquisa-ação. Isto é, tratou-se de não somente compreender o plano de conceitos e a Teoria Ontopsicológica 
como um todo, mas perceber, estruturar e confirmar sua aplicabilidade, no caso desta pesquisa, no contexto empresarial. As várias abordagens por nós realizadas são elementos que unem a fonte científica e conceitual presentes nas obras que selecionamos do Professor Acadêmico Antonio Meneghetti e a realidade viva das organizações, mais propriamente da realidade organizacional da empresa ICM obras.

\section{Resultados e Discussão}

O resultado até aqui é sutil e se evidencia na forma de comportamento das pessoas em relação à empresa, bem como na constatação diária da harmonia, convivência e do espírito colaborativo durante o desenvolvimento dos trabalhos. Pessoas com aparência saudável, alegre, e que não faltam ao trabalho, são um resultado intangível, um ativo de valor conceitual para a organização. Também a análise da rotatividade e do índice de reclamatórias trabalhistas é fator importante na verificação da qualidade das relações da empresa com seus profissionais. Nos 16 anos de existência da empresa em estudo, foram quatro reclamatórias trabalhistas formalizadas, sendo que uma foi resolvida em acordo, uma por sentença favorável ao reclamante no valor de dez por cento de sua petição inicial, uma por sentença a favor da empresa.

$\mathrm{Na}$ primeira semana de agosto de 2016 foi realizada uma pesquisa onde os profissionais da empresa responderam por escrito a quatro perguntas. A primeira referia-se à possibilidade de pedir demissão por oferta de trabalho com salário maior em outra empresa. A maioria das respostas indicou que sempre existem propostas que acenam melhor salário, mas não há a segurança que existe na ICM Obras, a qual o salário sempre é pago com pontualidade.

A segunda pergunta foi sobre a motivação em trabalhar nesta empresa, considerando que outra poderia pagar salário igual ou até maior. Quase todas as respostas indicaram que máquinas e equipamentos que contribuem na facilitação do trabalho são grande incentivo para permanecer no emprego.

A terceira pergunta se deu acerca da possibilidade de evolução pessoal e profissional que a ICM Obras propicia. Nessa questão as respostas foram bastante enfáticas do quanto é agradável trabalhar na empresa, que provoca e oportuniza crescimento, que cultiva relações de respeito e o profissional tem ampla liberdade para desenvolver seu próprio aprendizado. 
Por fim, uma quarta pergunta foi em relação à família: que valor ela dá para o fato de um familiar estar trabalhando na ICM Obras. As respostas versaram em torno do valor do pagamento do salário em dia, a possibilidade de crescimento, a estrutura da empresa e uma resposta em particular chamou atenção: a família vê como valor o trabalhador estar feliz com o trabalho.

\section{Considerações Finais}

Para que este programa tenha condições de ser verificado na prática, é necessária uma gestão que reforce permanentemente a filosofia meritocrática na empresa, formalizando indicadores de desempenho, critérios de ação padronizados e instrumentos que permitam aferir os resultados de forma clara e assim certificar a validade do método.

Também os critérios de admissão e seleção de novos profissionais são baseados em modelo fundamentado na Psicologia Ontopsicológica, especialmente os indicativos de uma boa e eficiente entrevista do candidato ao trabalho (MENEGHETTI, 2013).

Assim, há pela frente um desafio duplo, o de implementar ações que se tornem perenes e atingir meios que possam dar fundamentação e garantia jurídica para as ações, especialmente as voltadas à meritocracia como valor e método.

\section{Referências}

MENEGHETTI, A. A Psicologia do Líder. 4. ed. Recanto Maestro: Ontopsicologica Editrice, 2008.

MENEGHETTI, A. Direitos e Deveres. In: Performance Líder, ano IV, II semestre, 2011.

MENEGHETTI, A. Psicologia Empresarial. Recanto Maestro: Ontopsicológica Editora Universitária, 2013.

MENEGHETTI, A. Os Jovens e a Ética Ôntica. Recanto Maestro: Ontopsicológica Editora Universitária, 2013.

\section{Apêndice:}

Como apêndice desta pesquisa seguem fotos que versam sobre as seguintes temáticas: Obras da ACM Obras, Equipes de Trabalho, Treinamento de colaboradores e Participação em Eventos: 


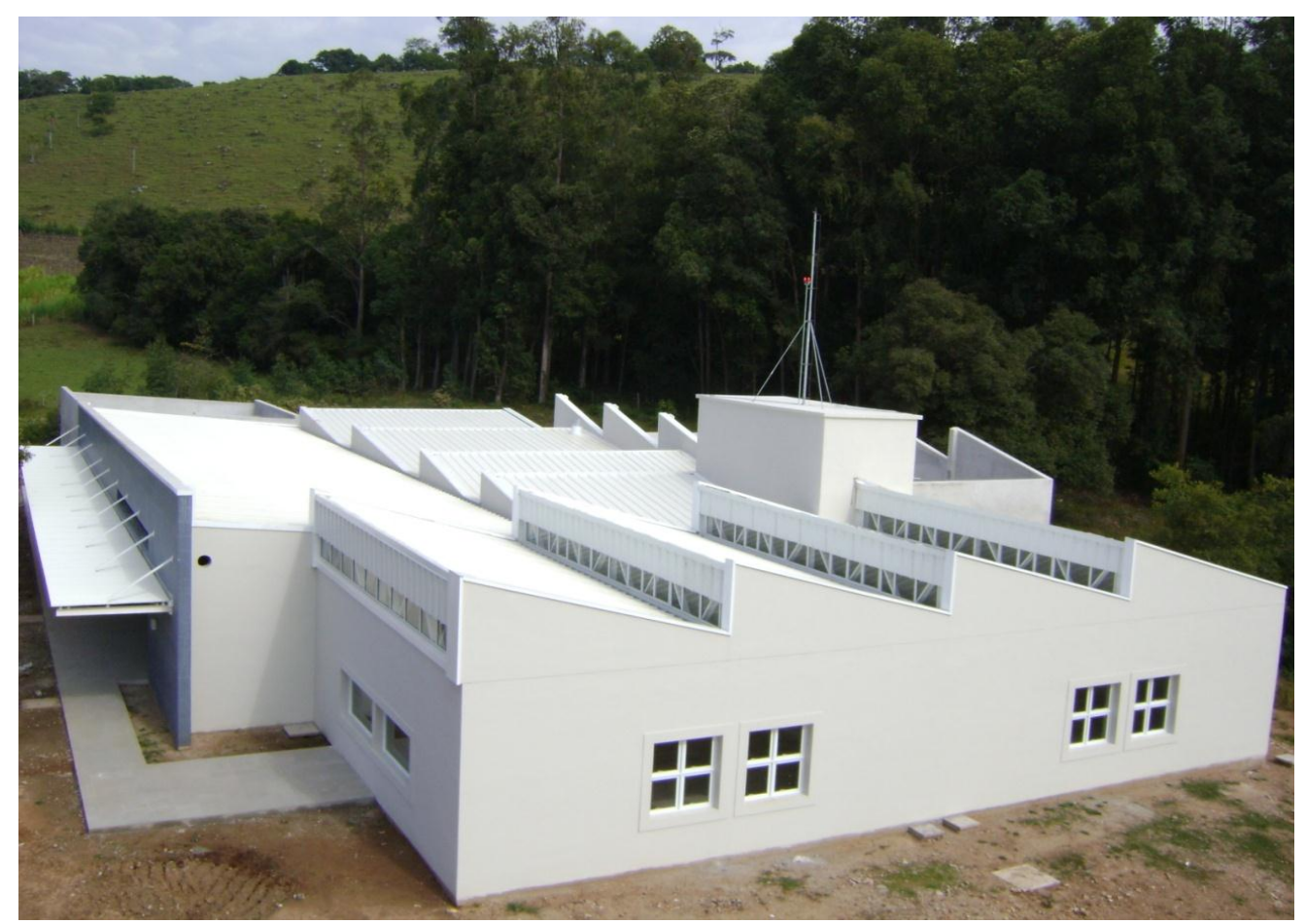

Figura 1

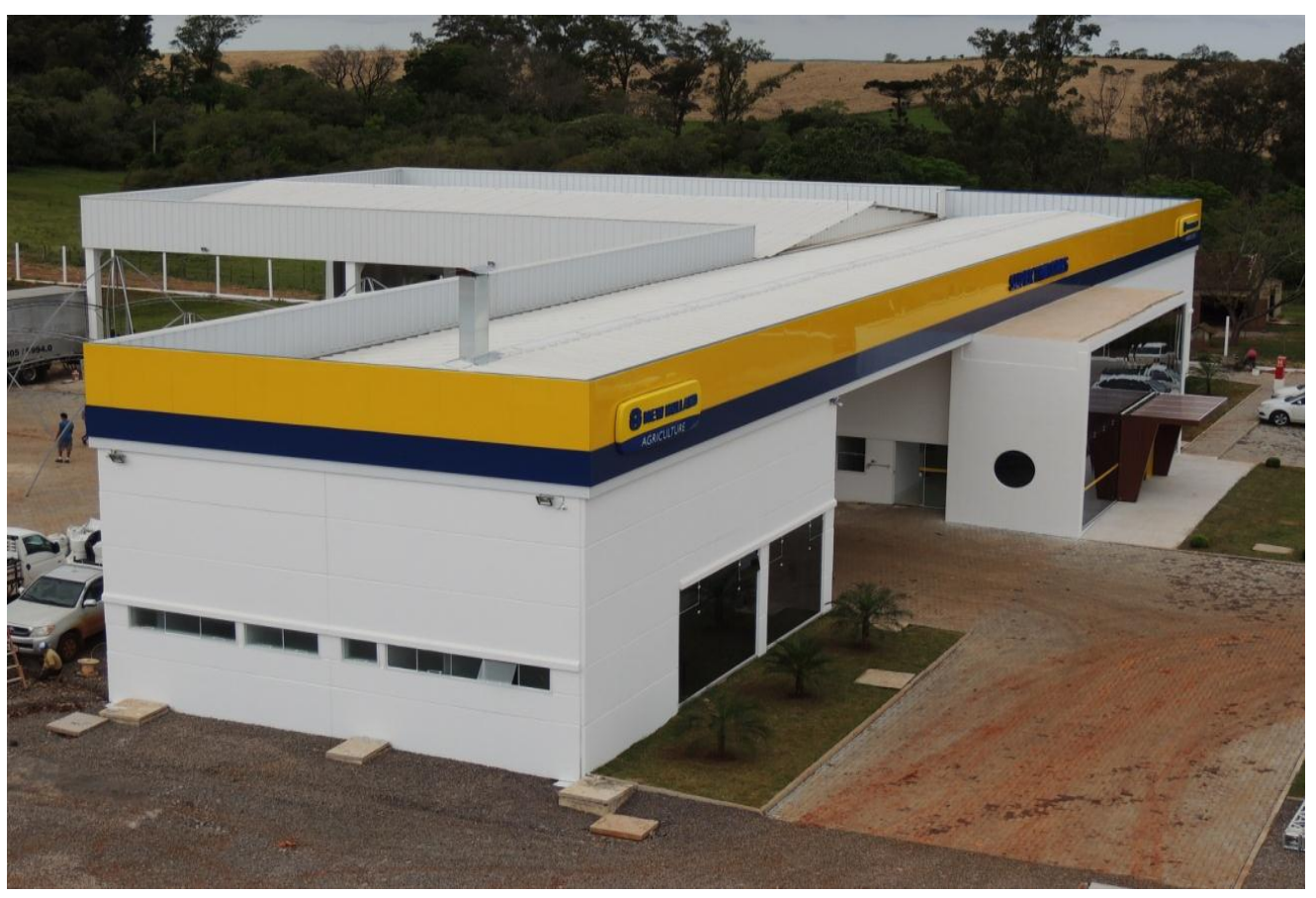

Figura 2 


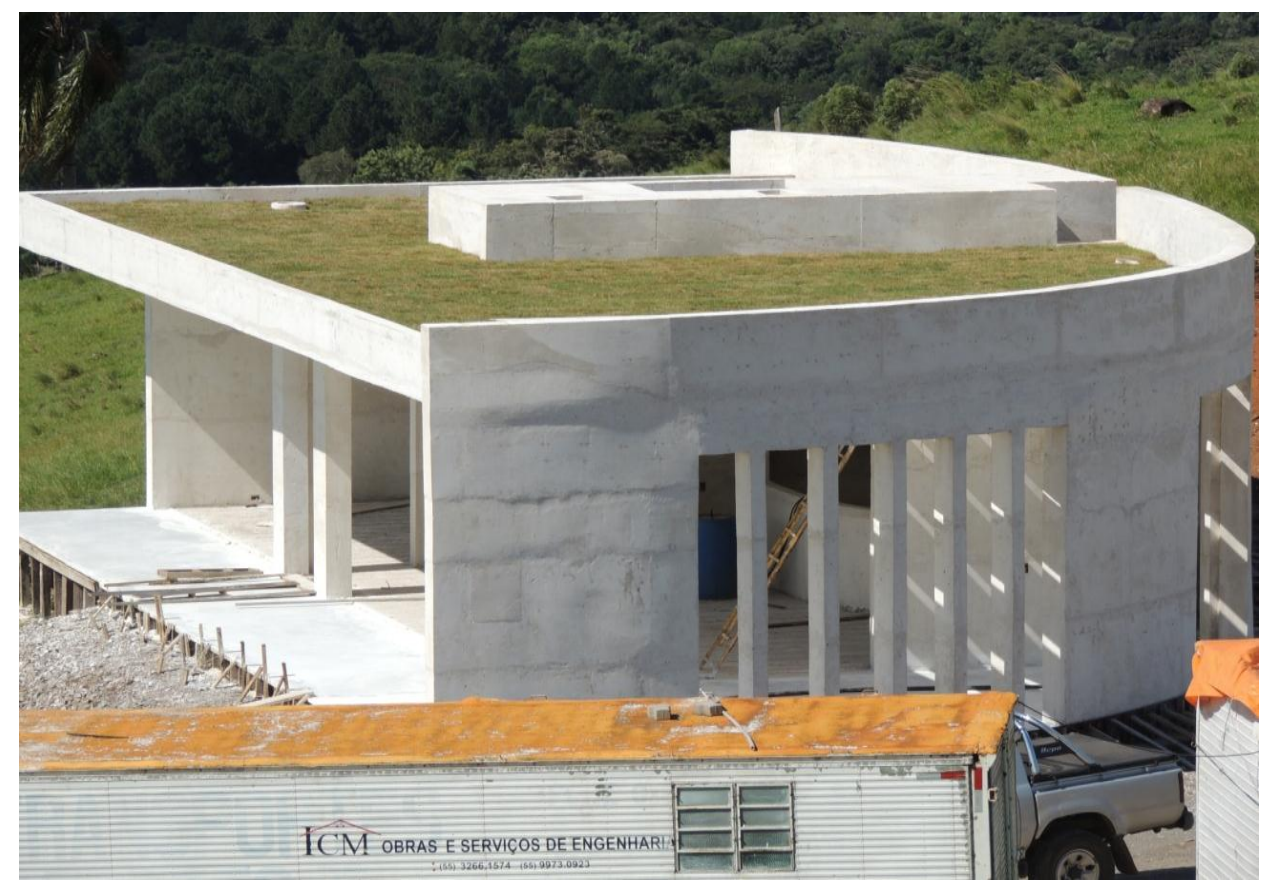

Figura 3

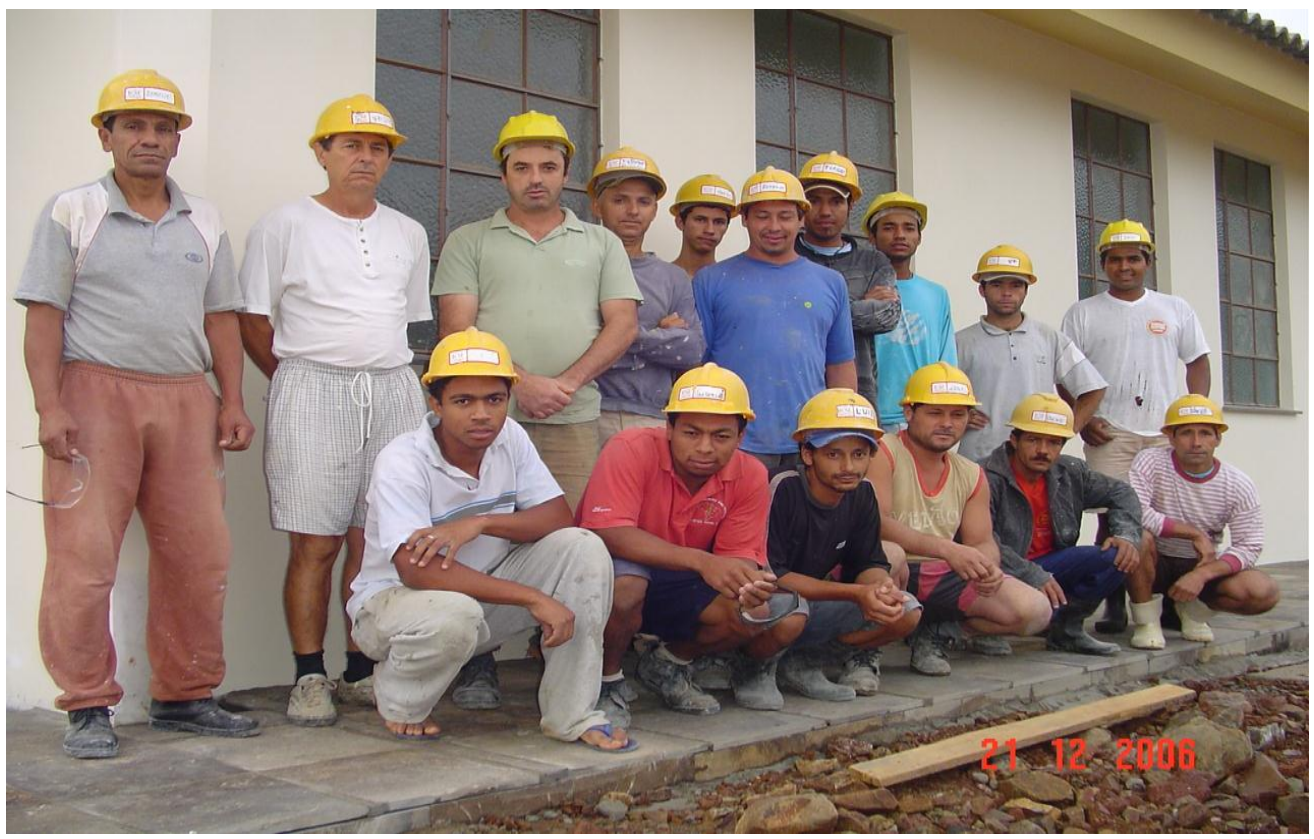

Figura 4 


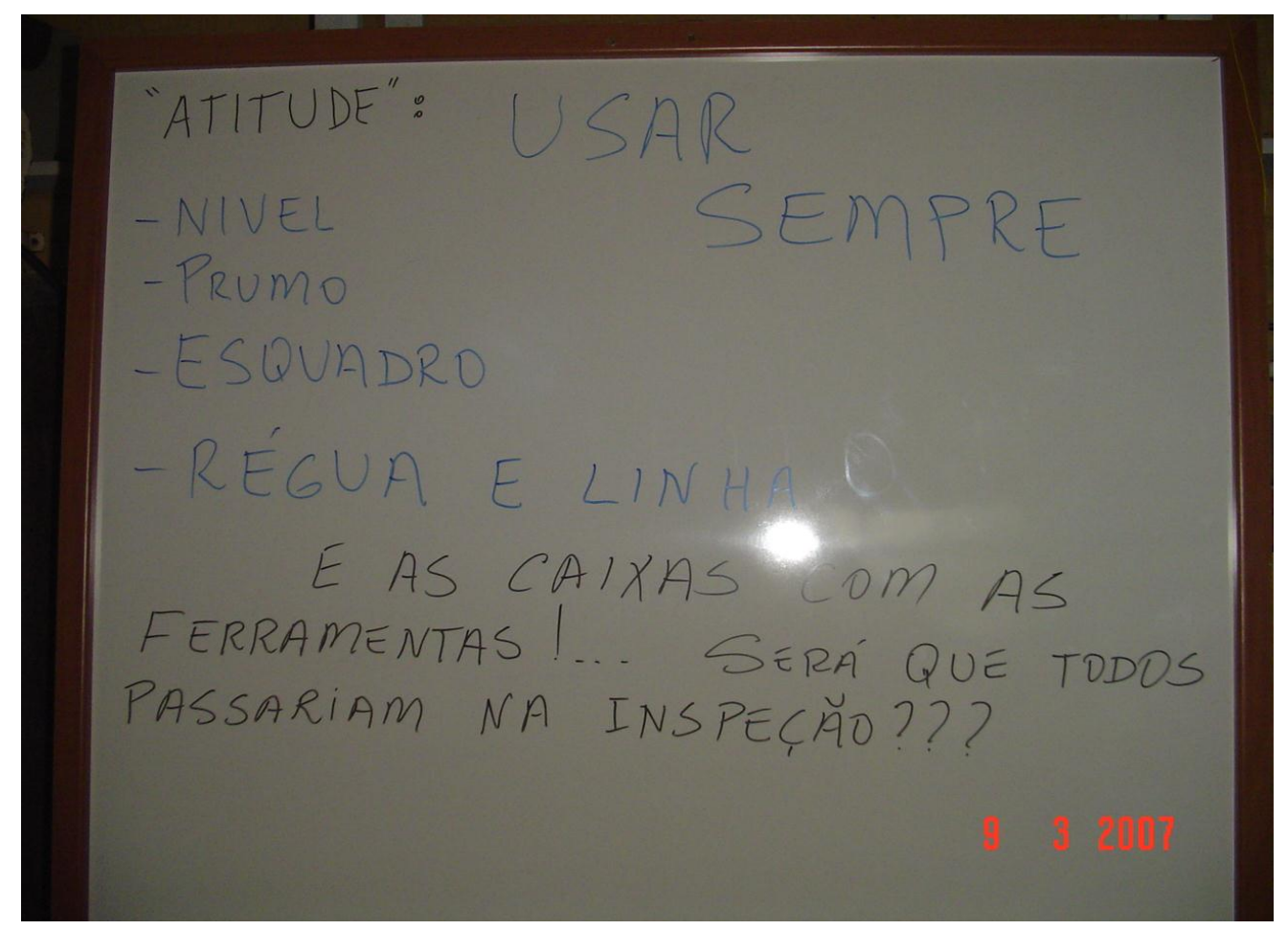

Figura 5

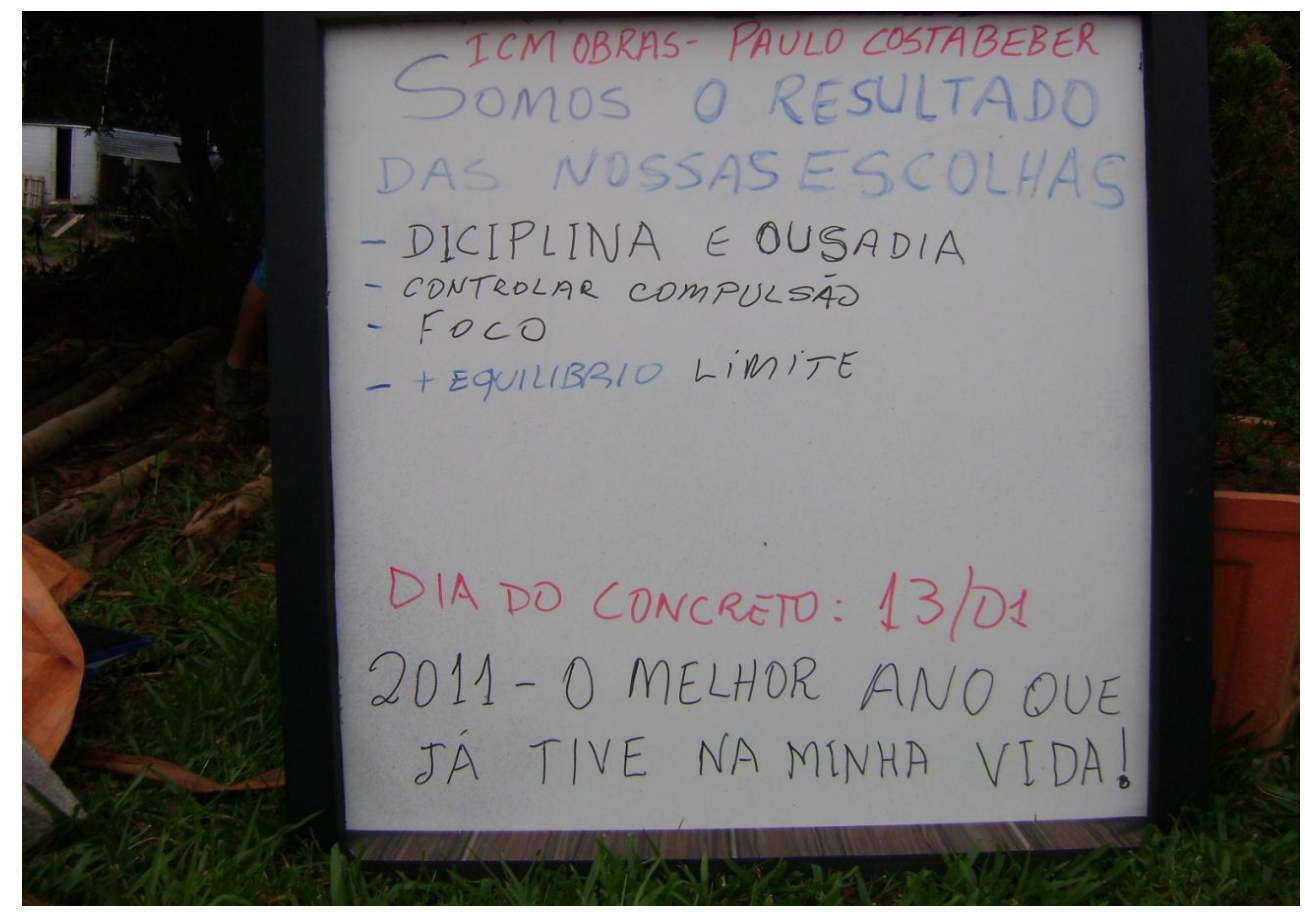

Figura 6 


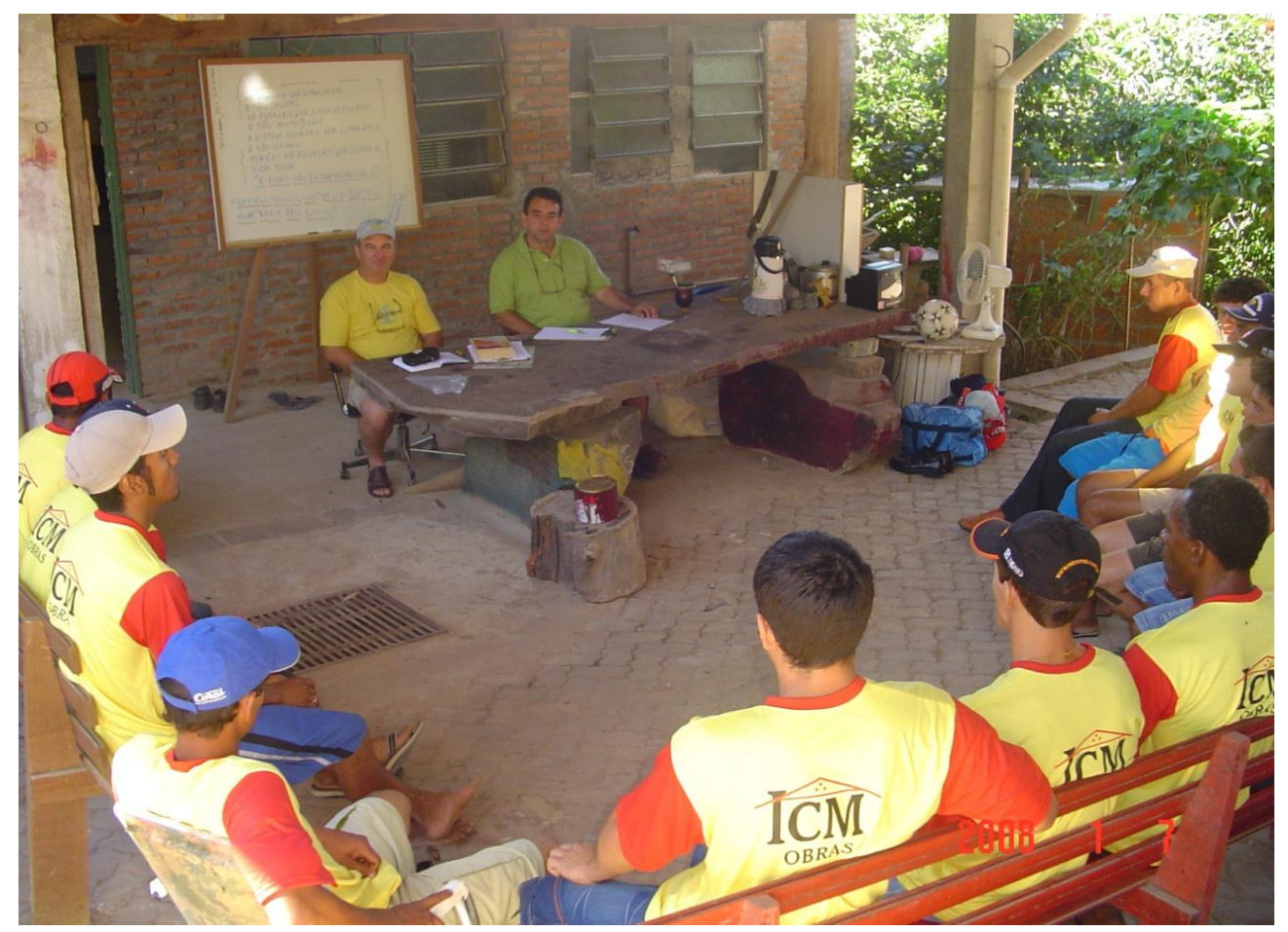

Figura 7

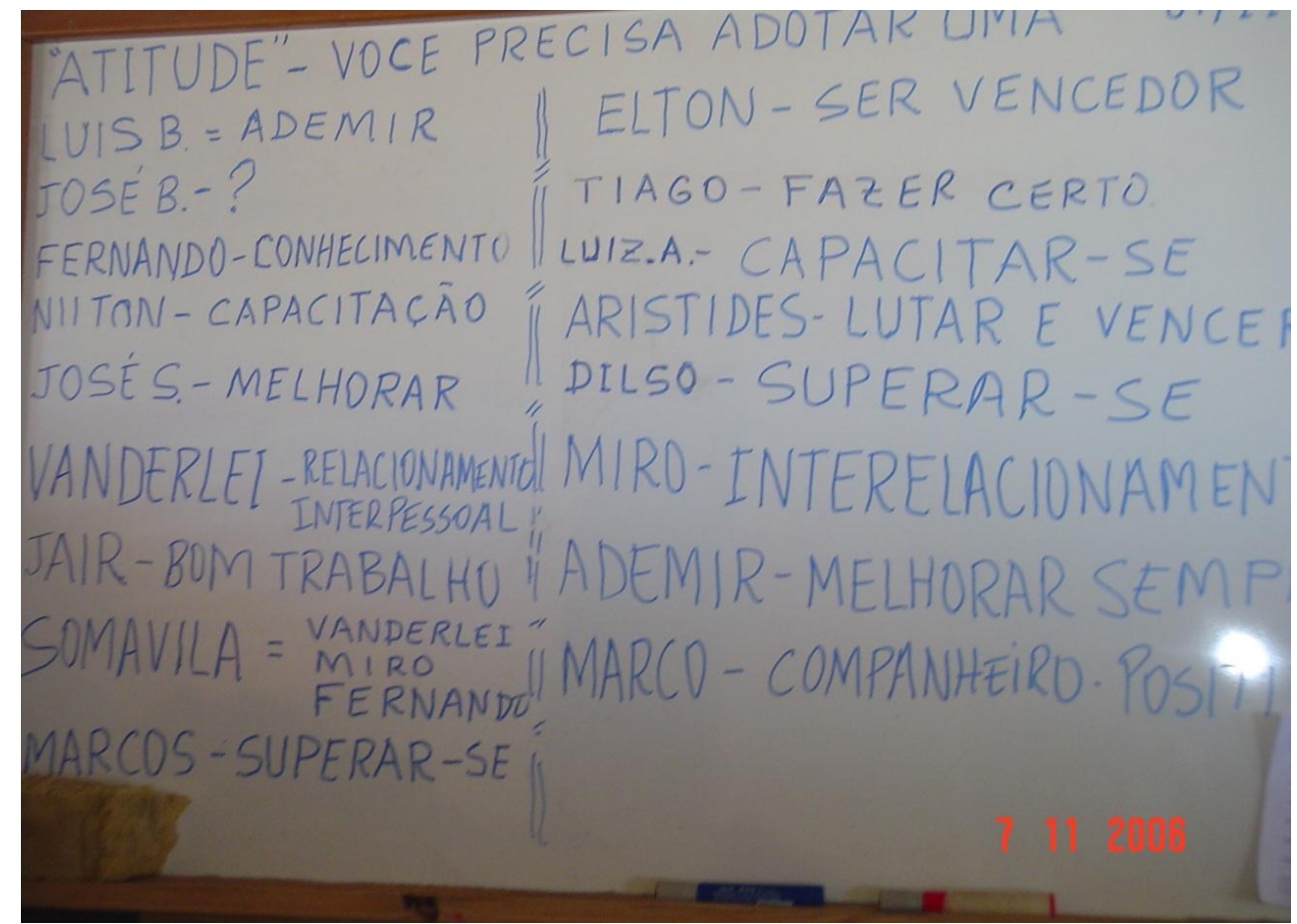

Figura 8 


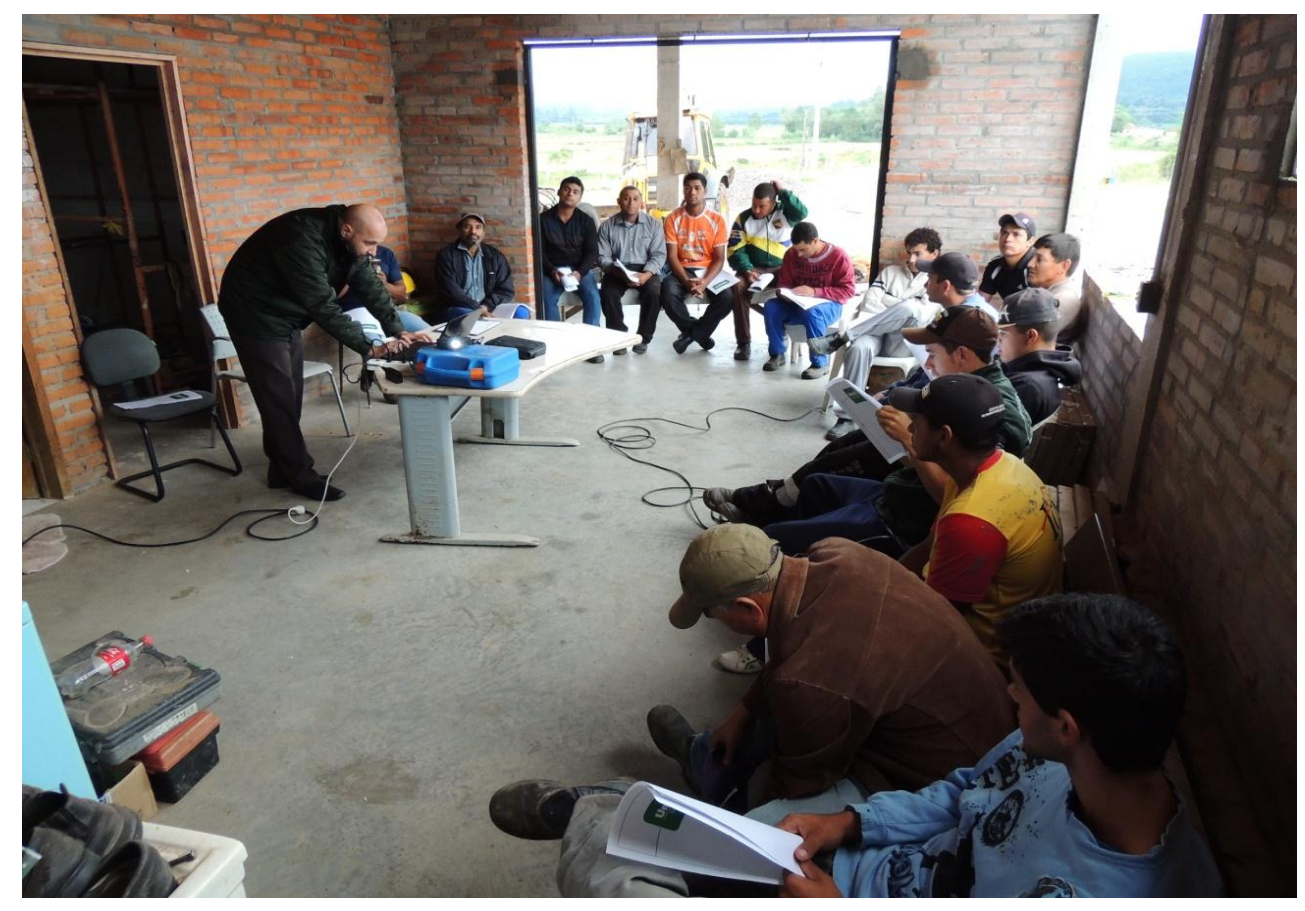

Figura 9

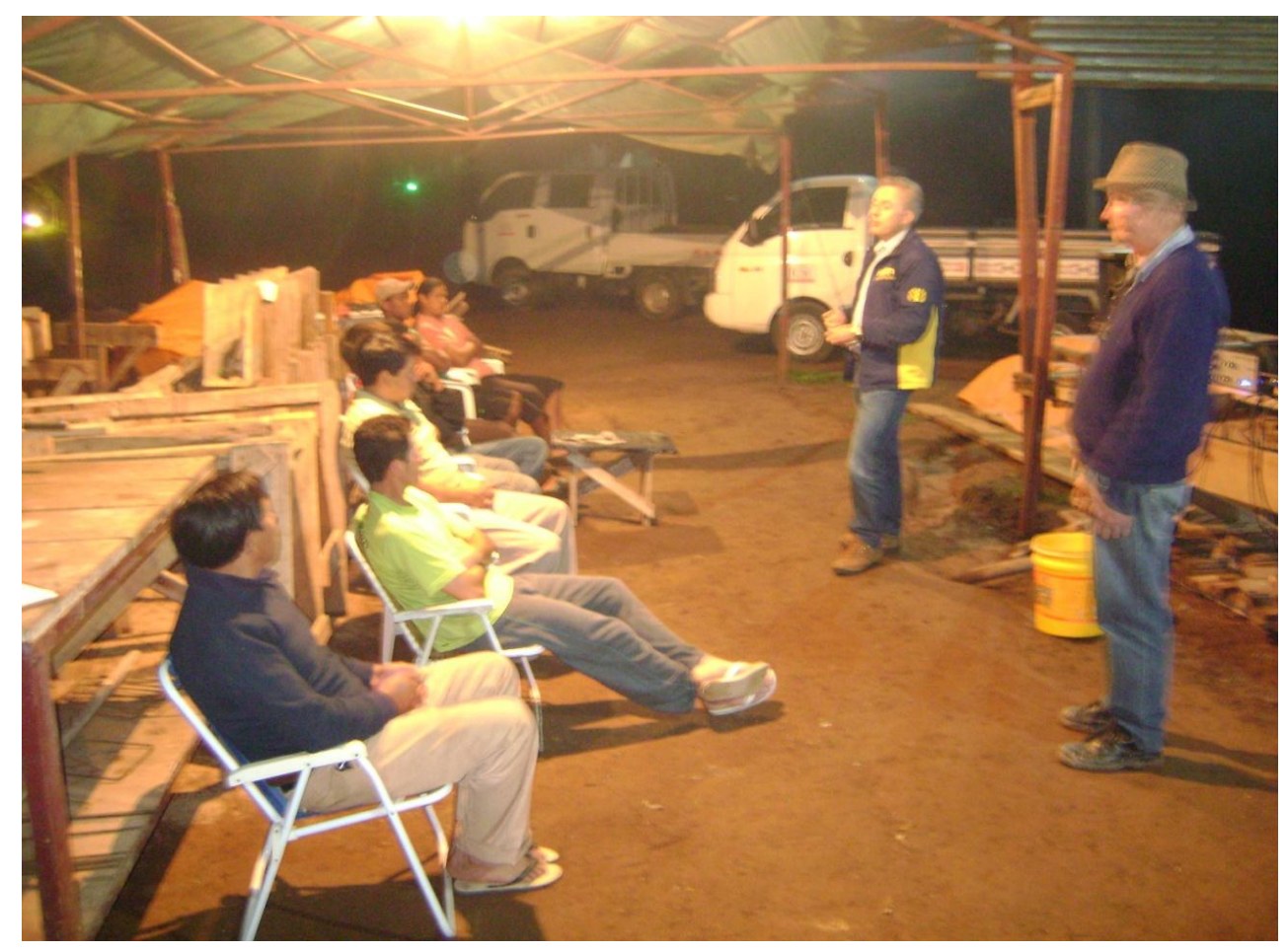

Figura 10 


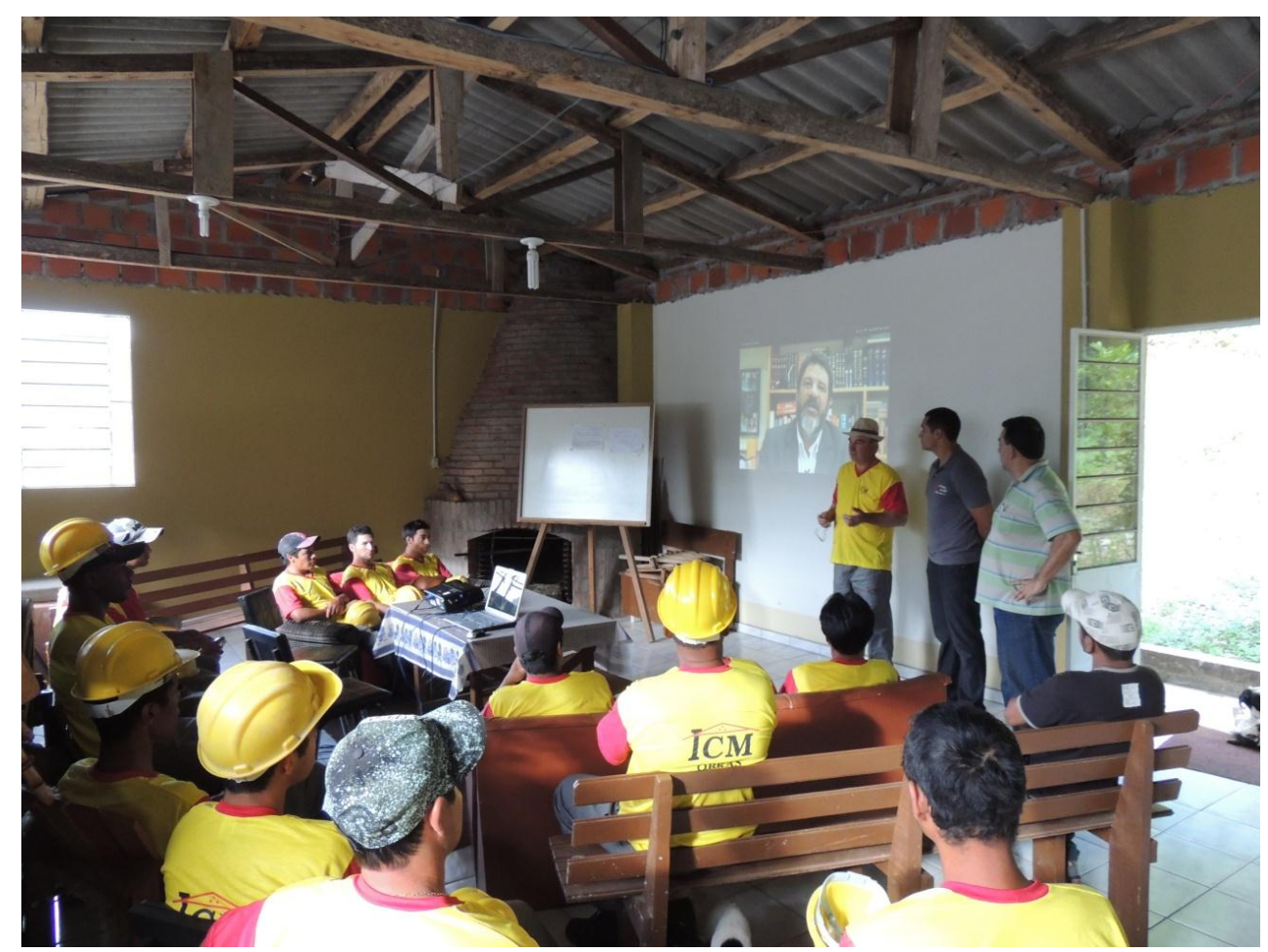

Figura 11

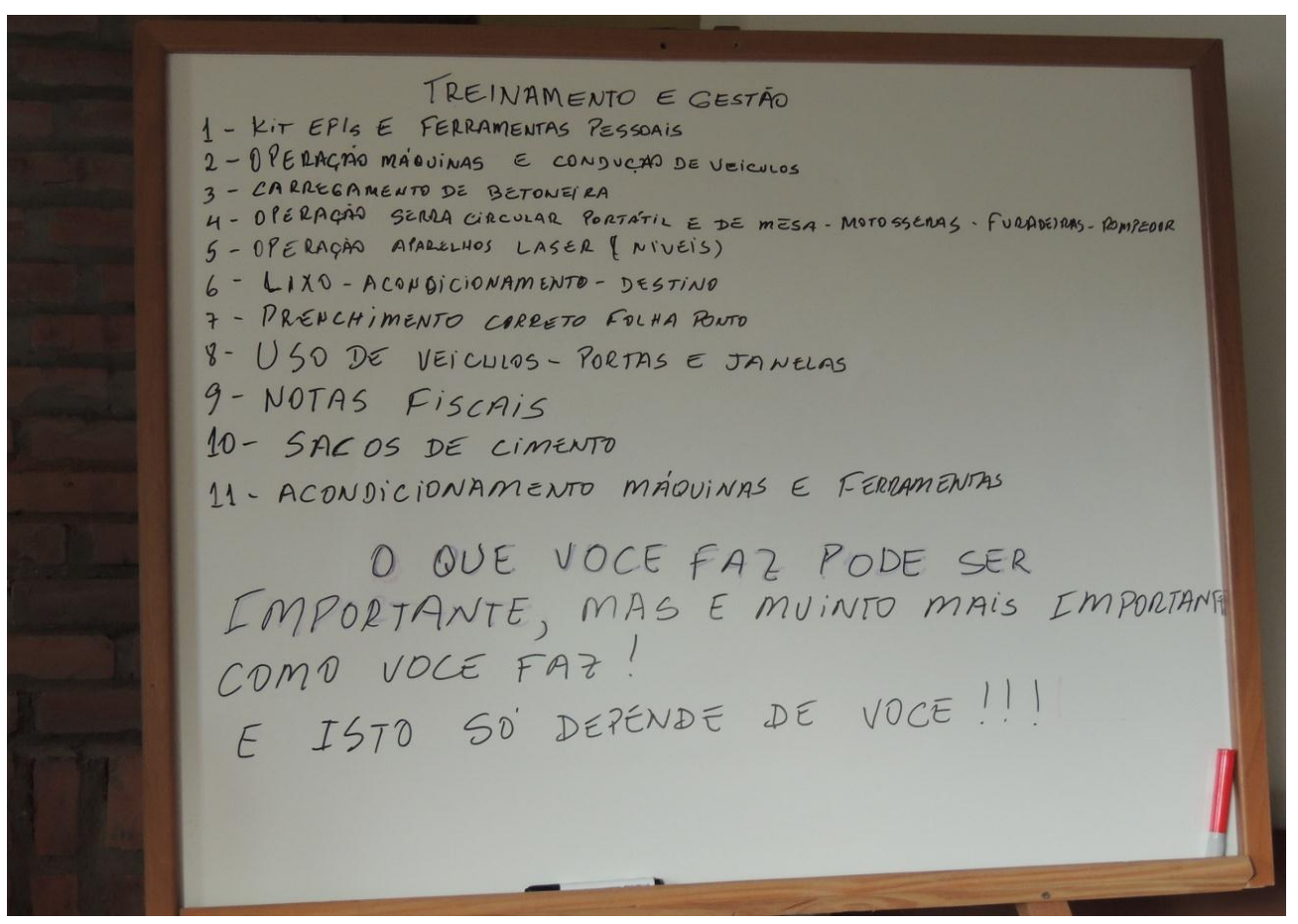

Figura 12 


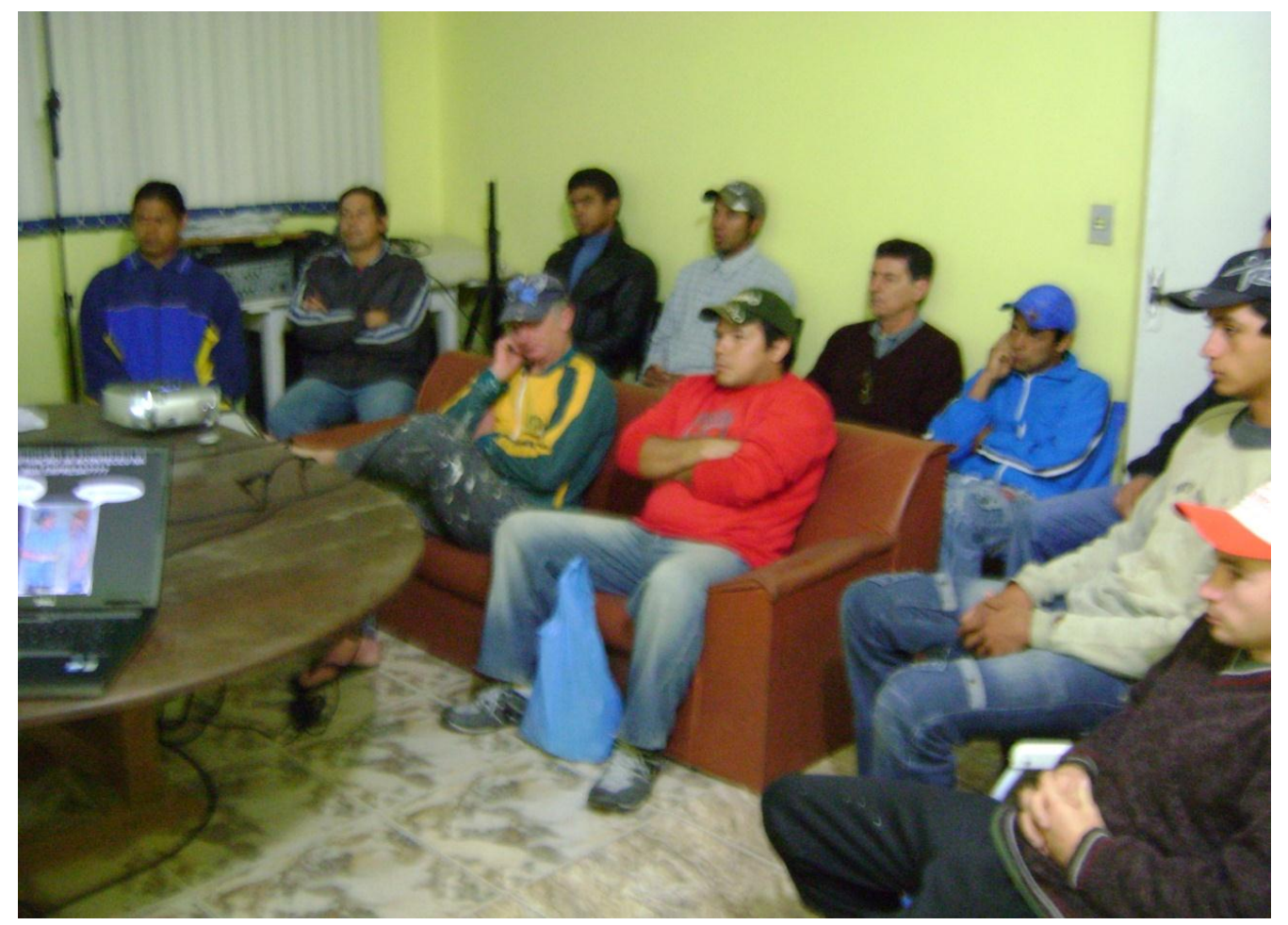

Figura 13

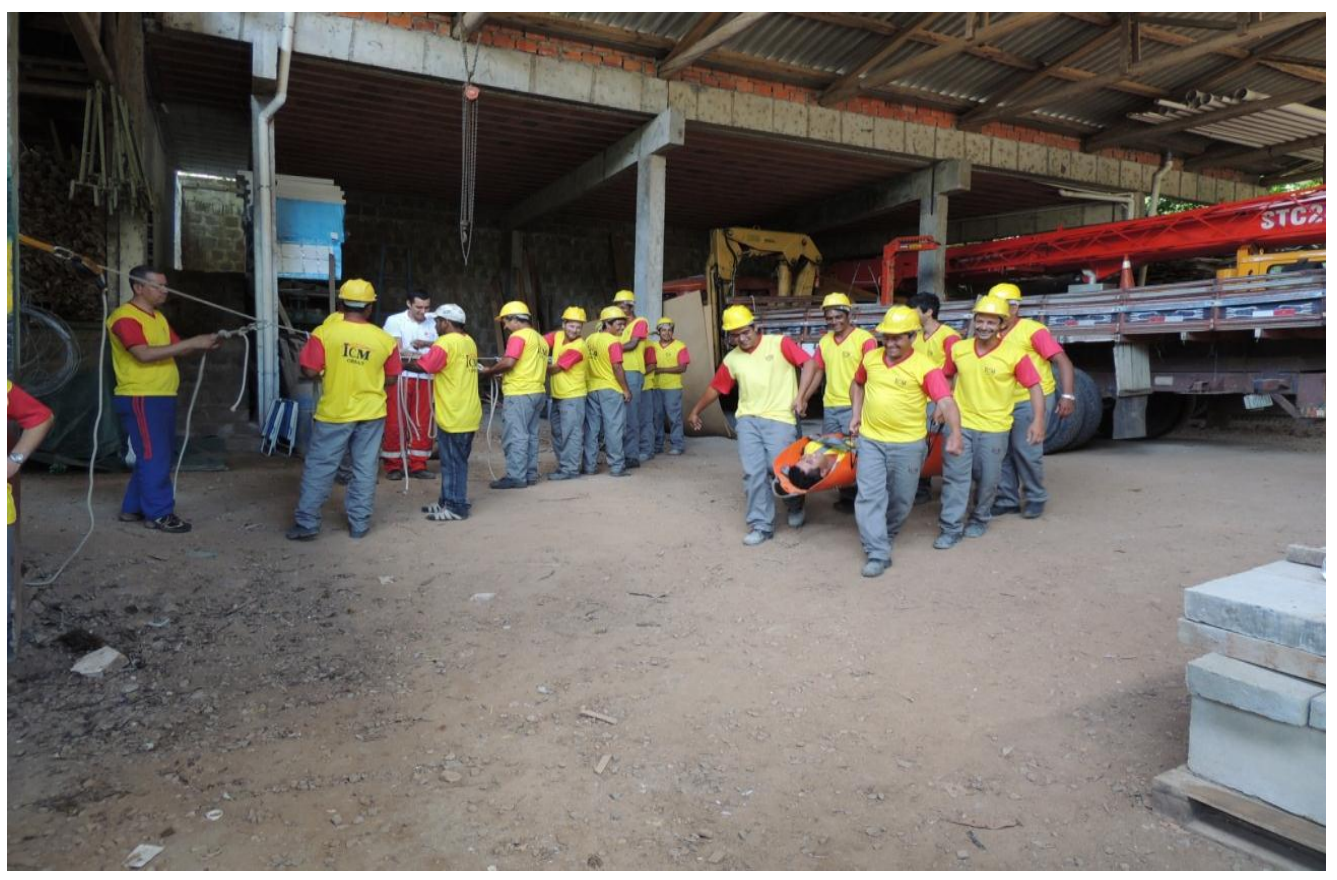

Figura 14 


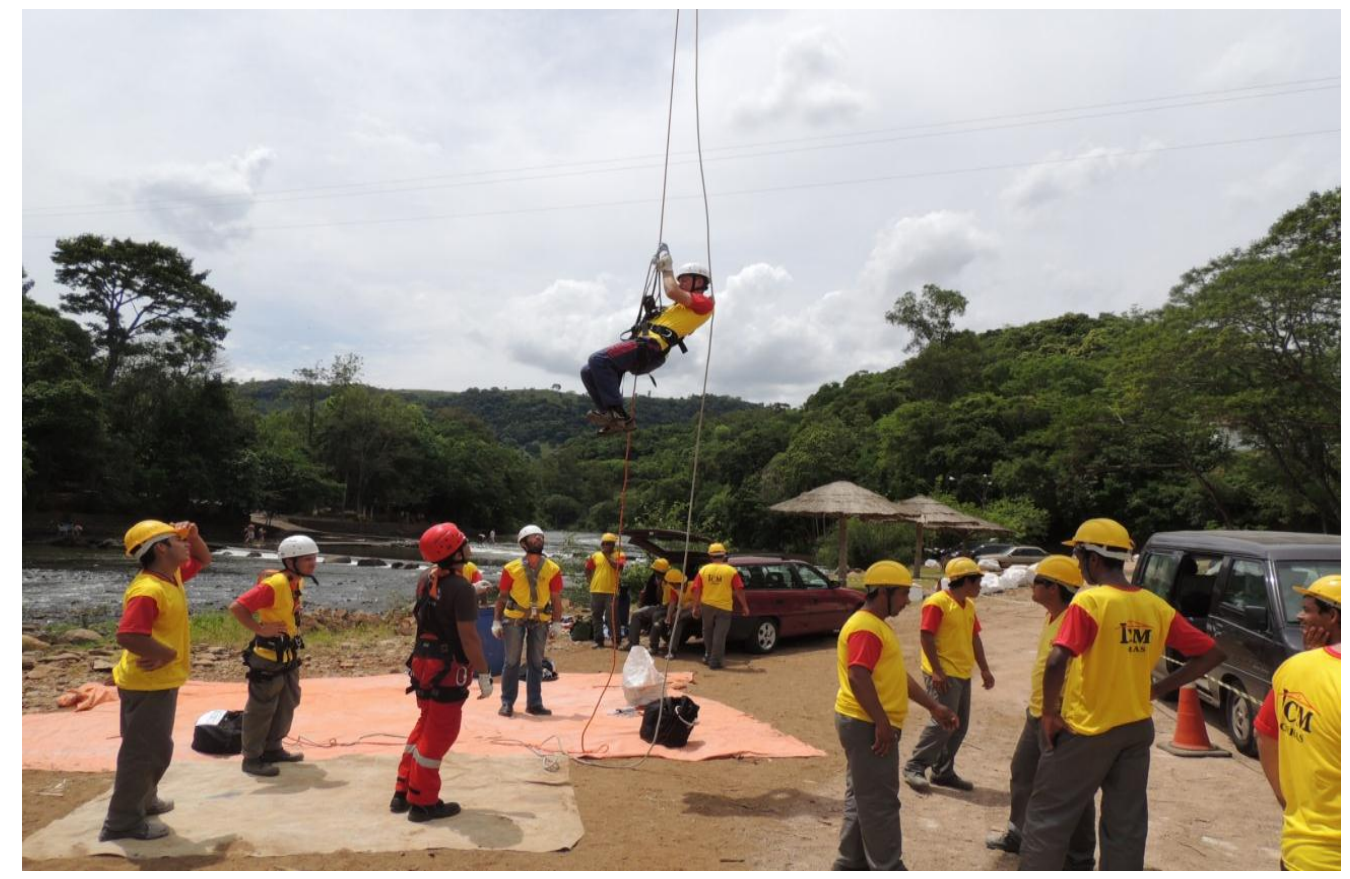

Figura 3

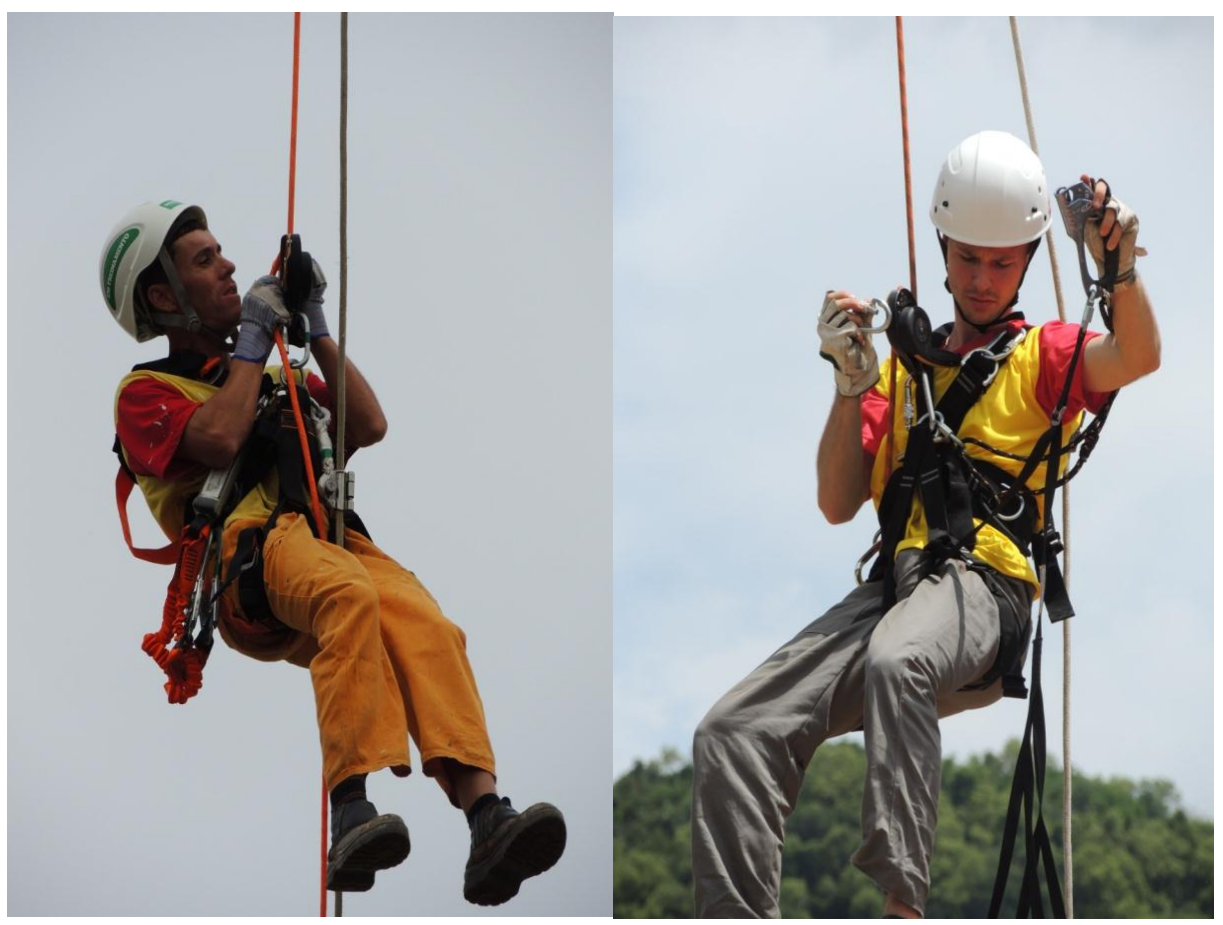

Figura 4 


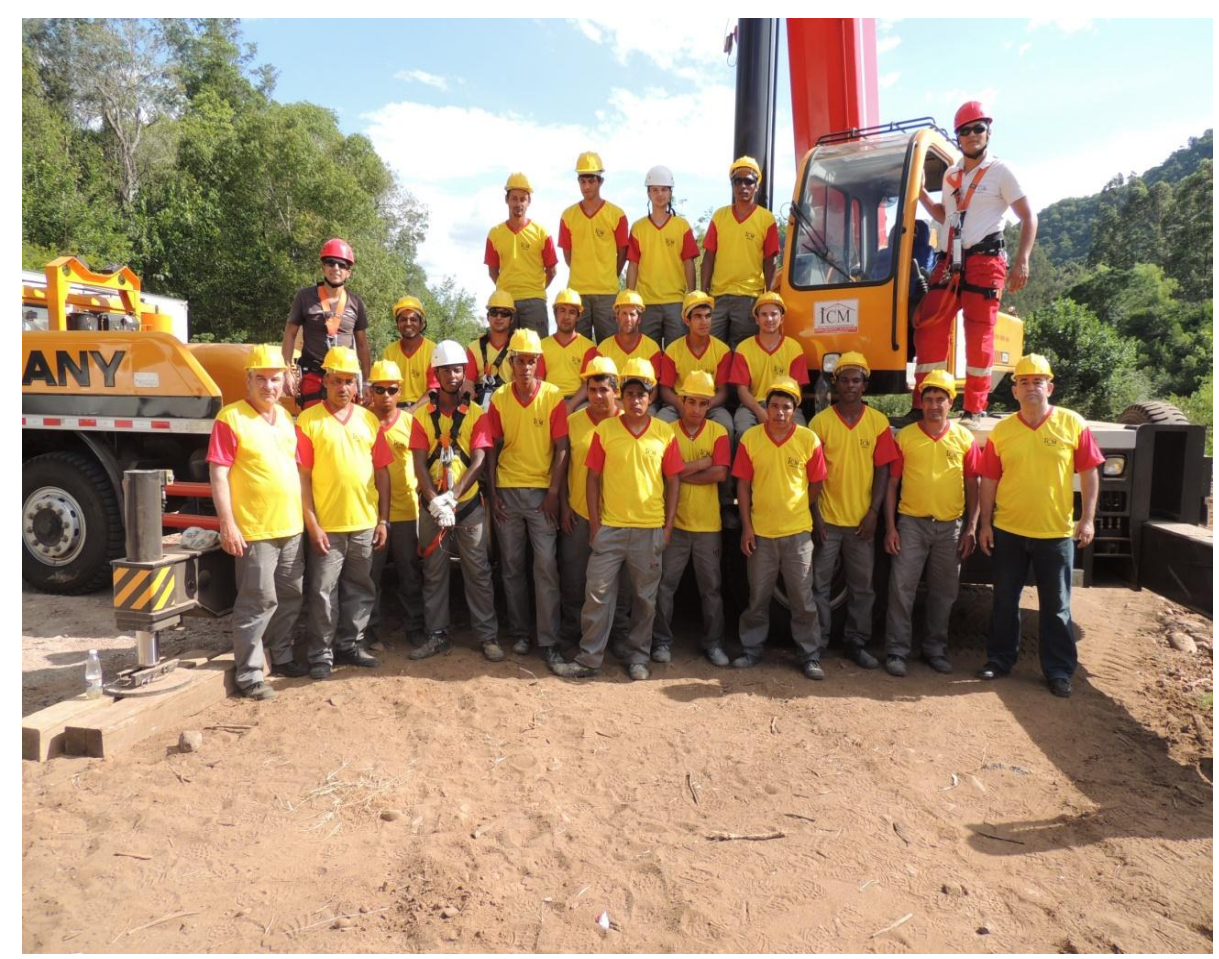

Figura 5

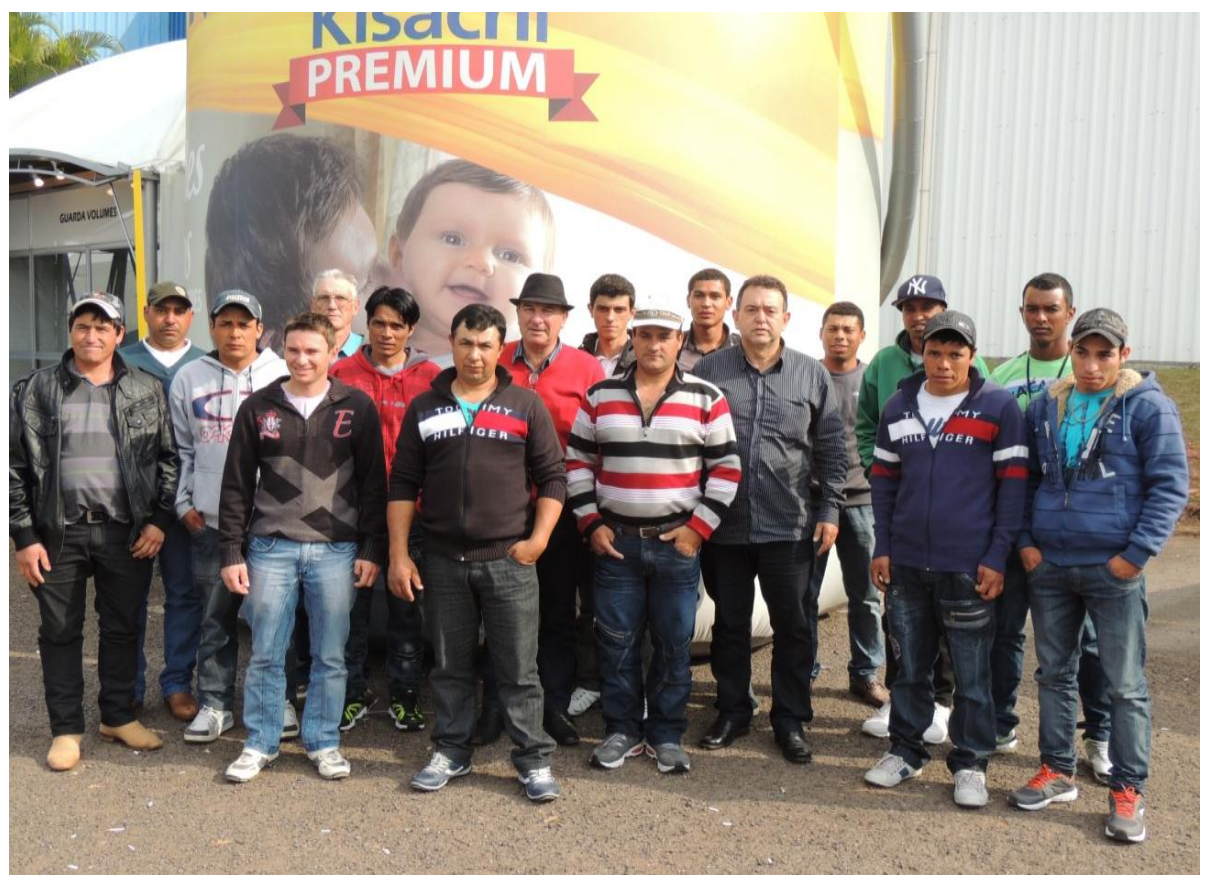

Figura 19 


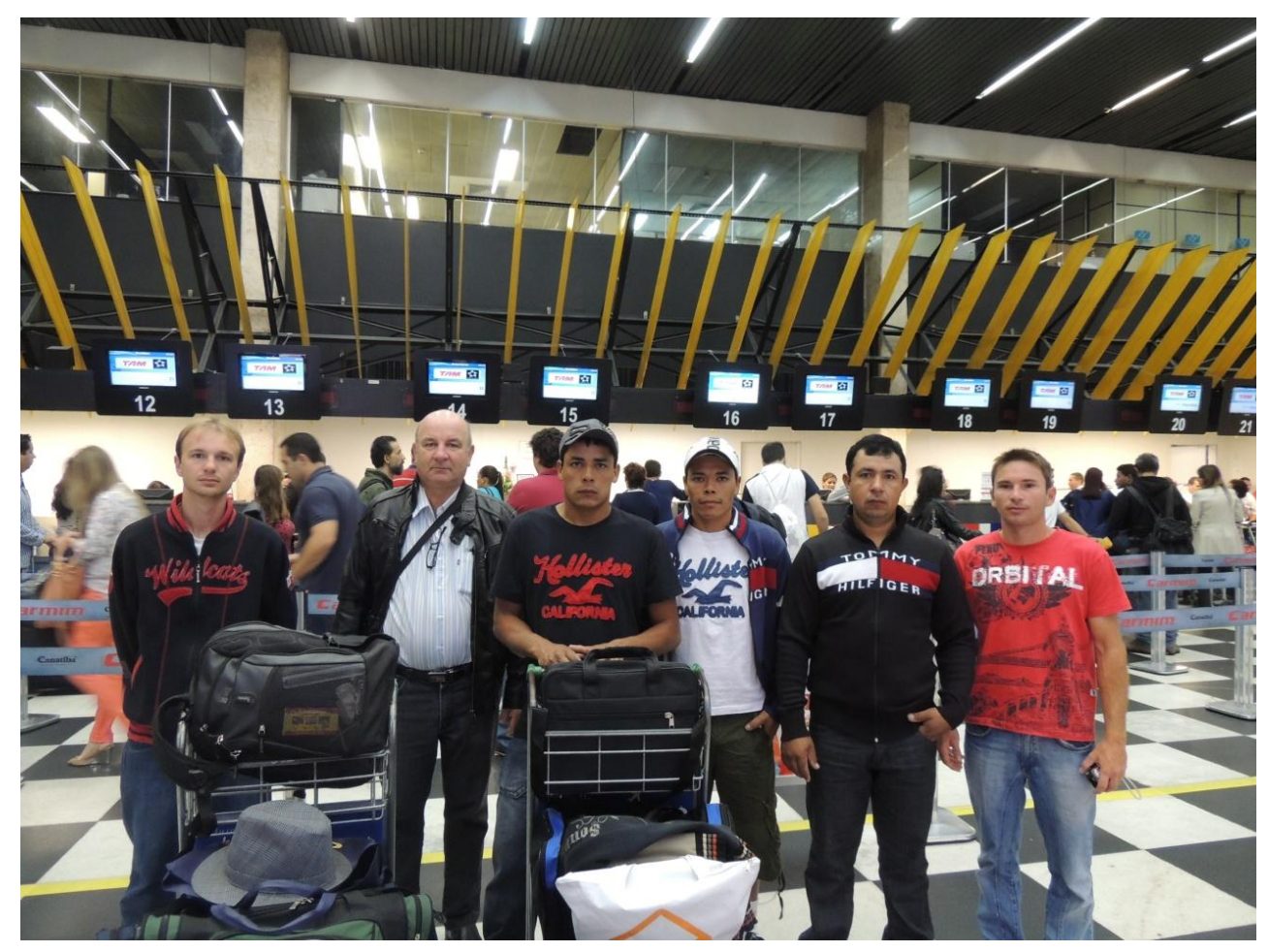

Figura 20

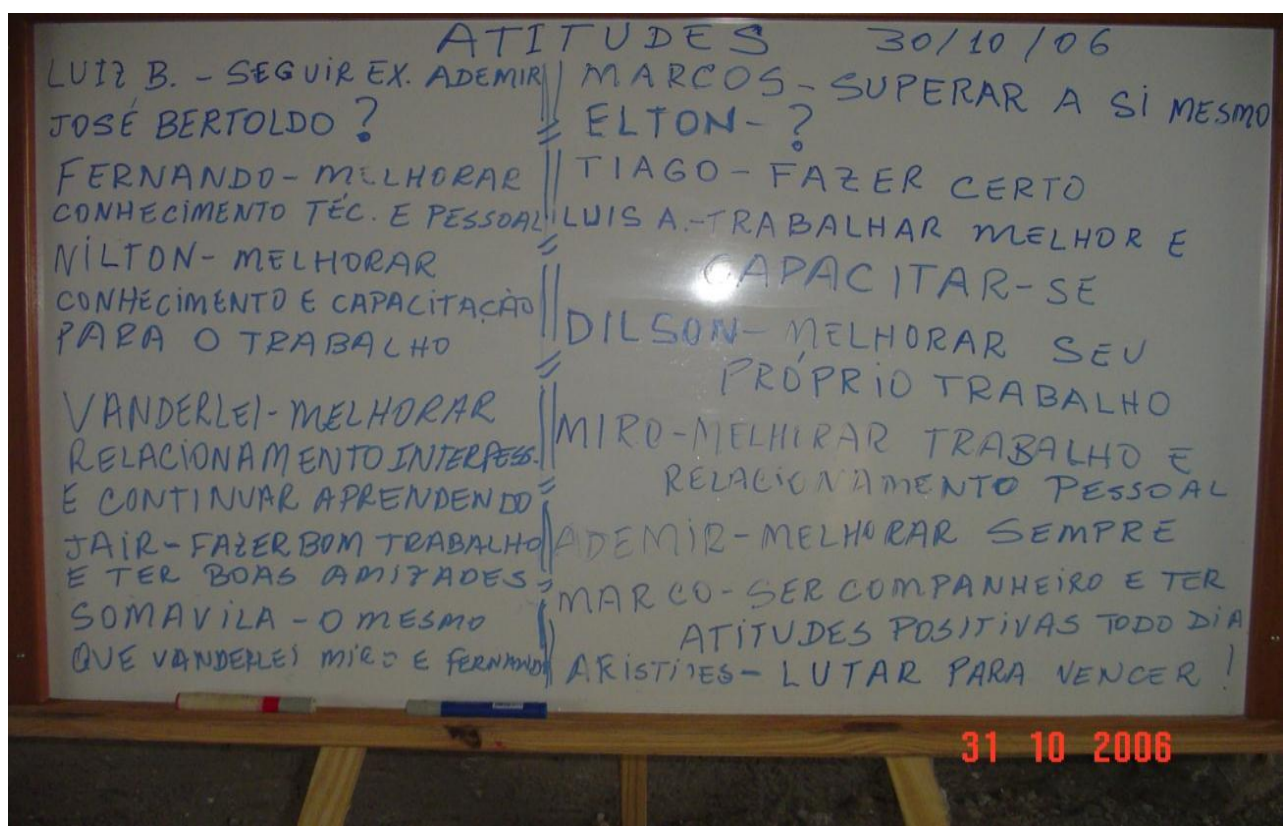

Figura 6 


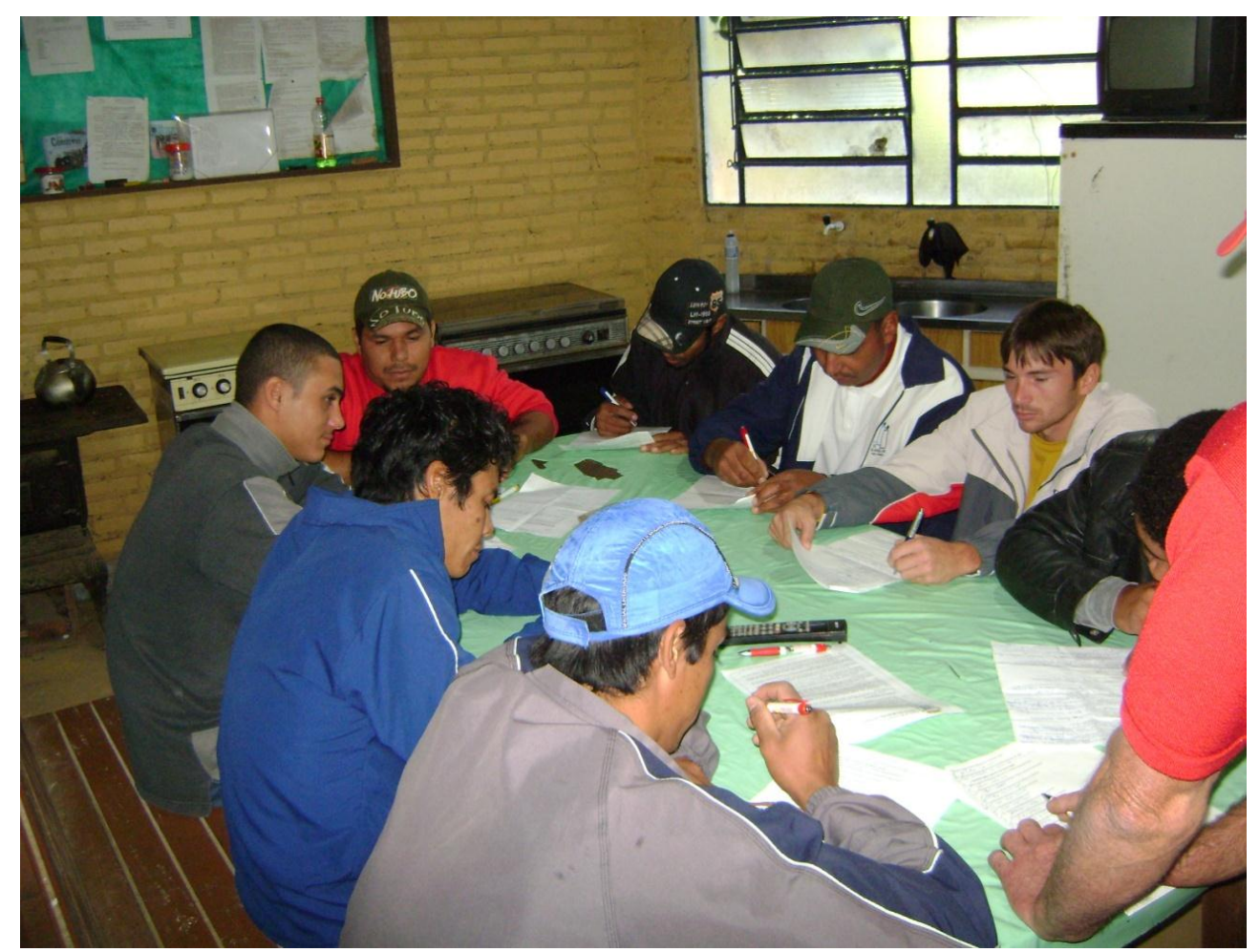

Figura 22

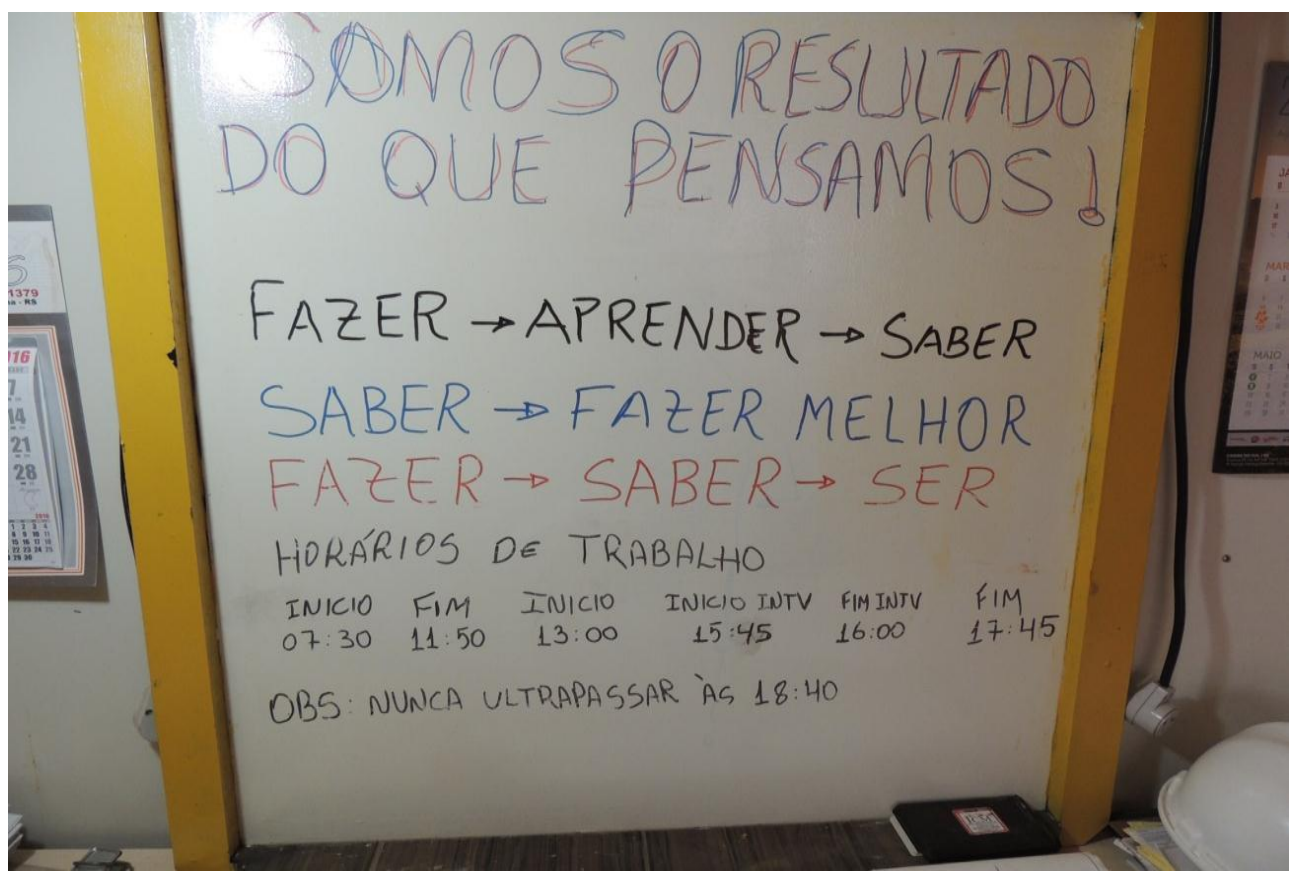

Figura 7 
Saber Humano, ISSN 2446-6298, Edição Especial: Cadernos de Ontopsicologia, p. 94-116, mar. 2018.

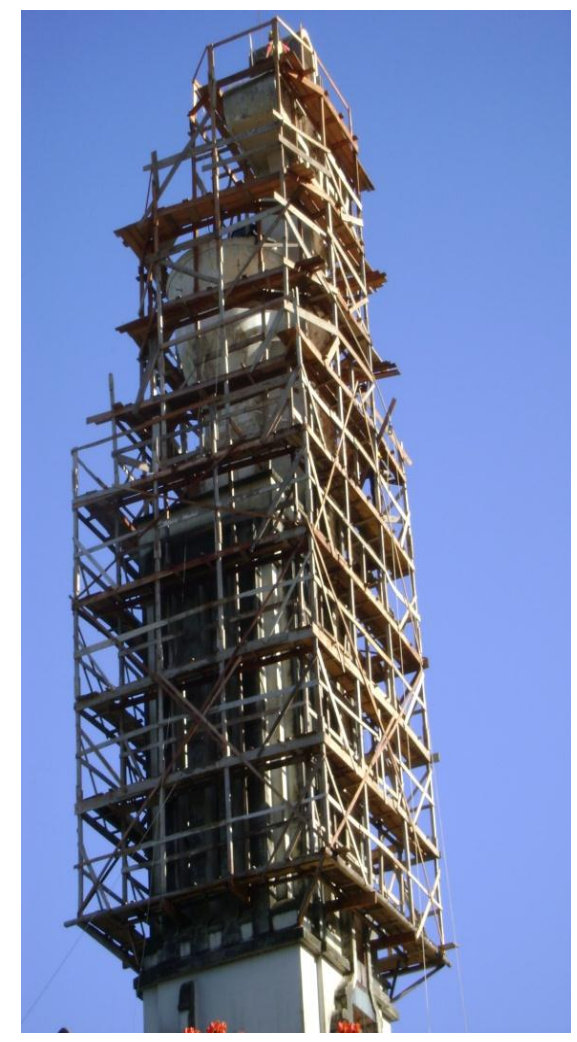

Figura 24

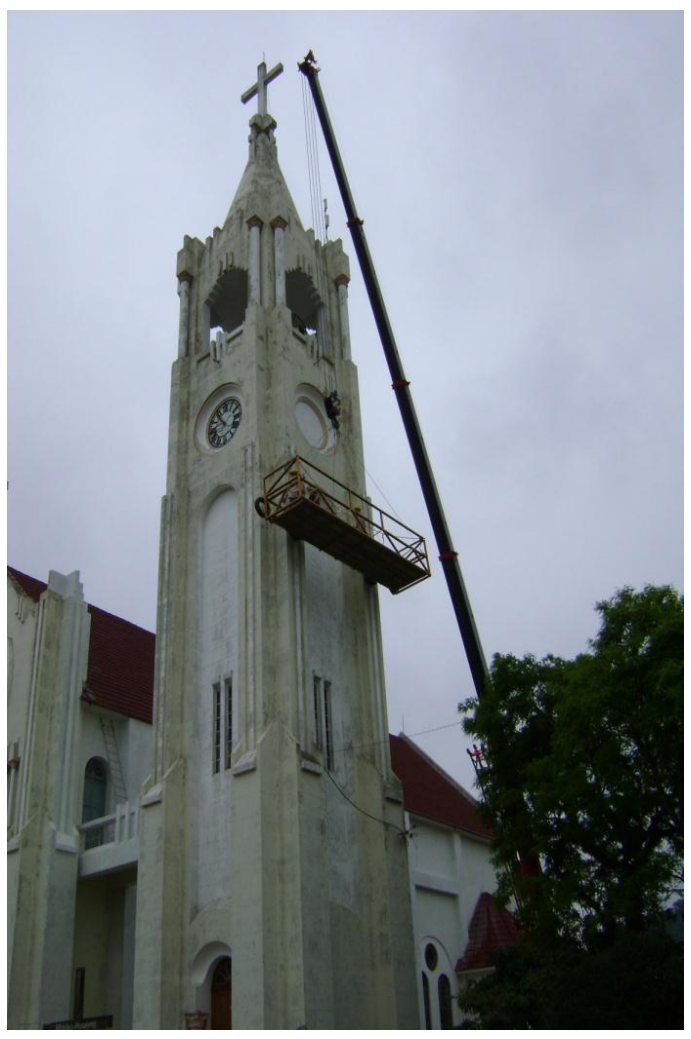

Figura 25 


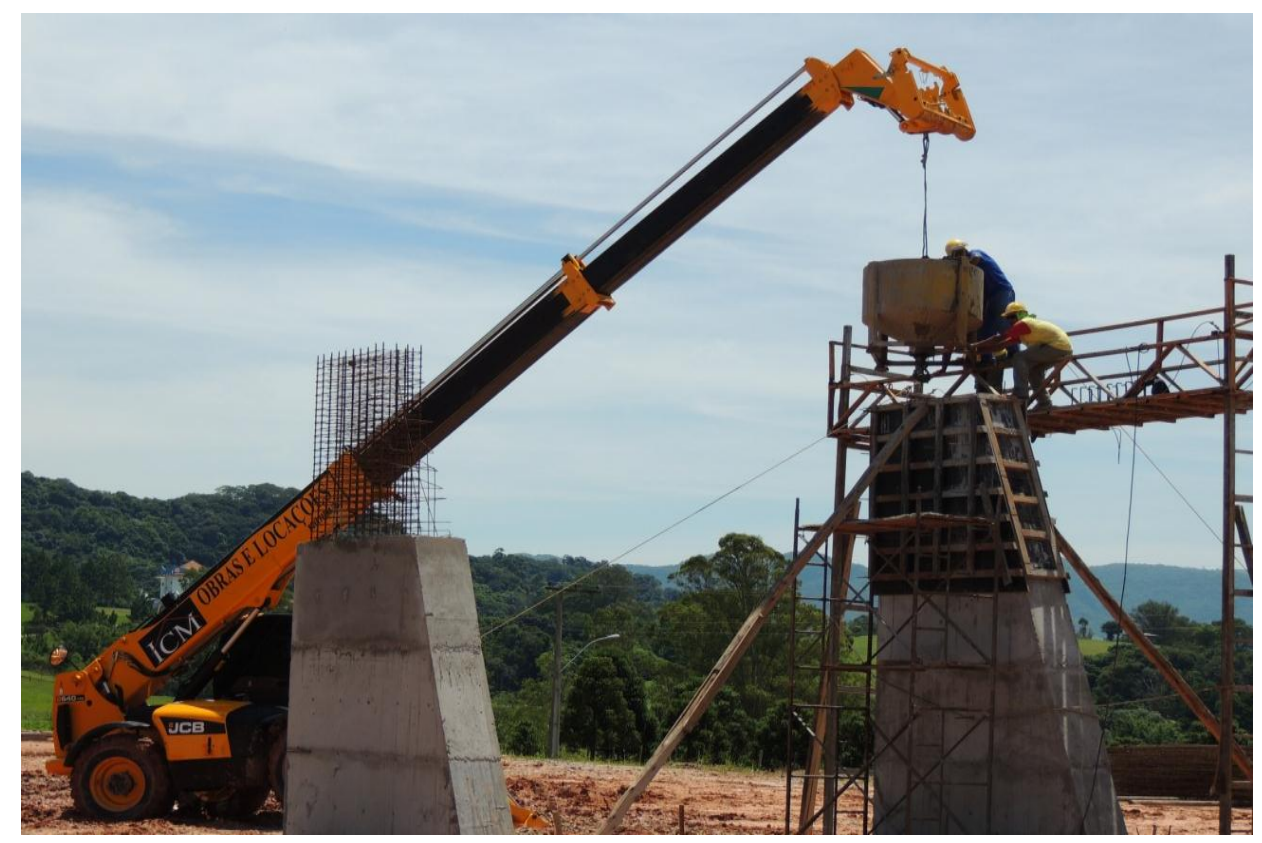

Figura 26

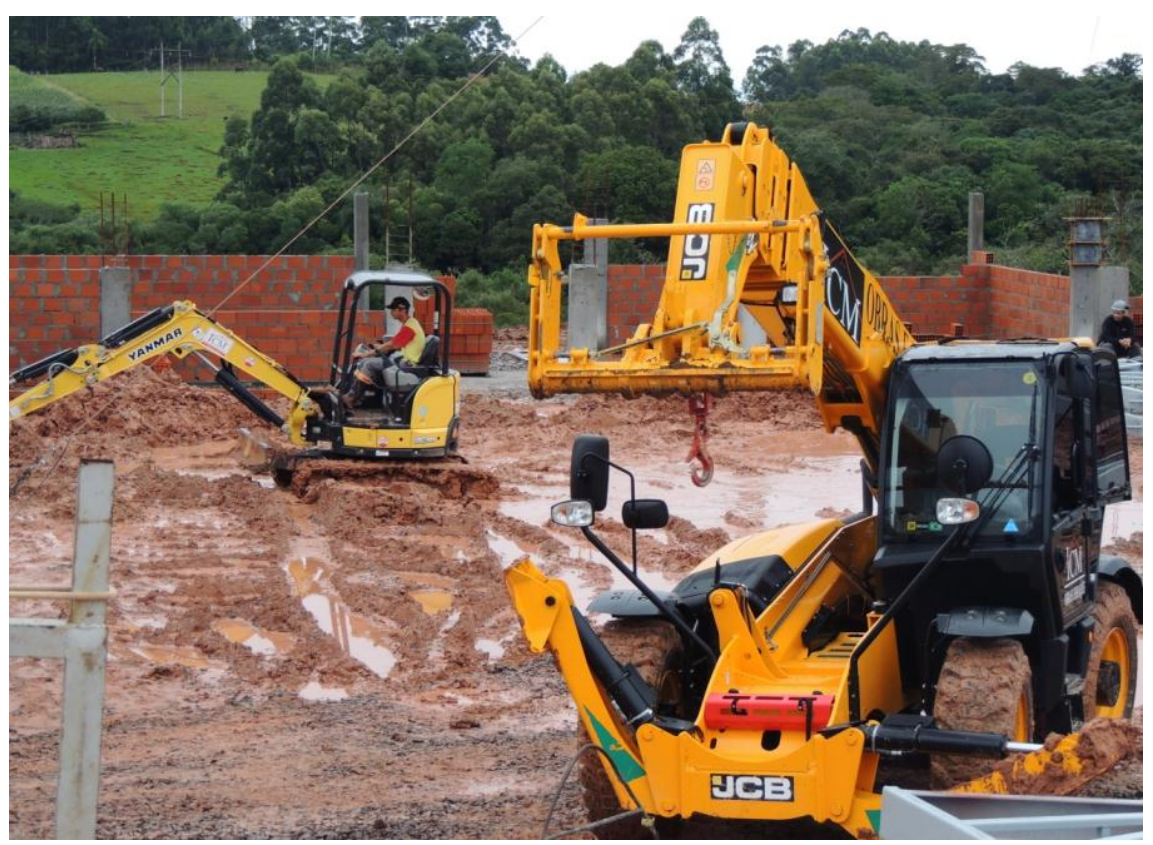

Figura 27 


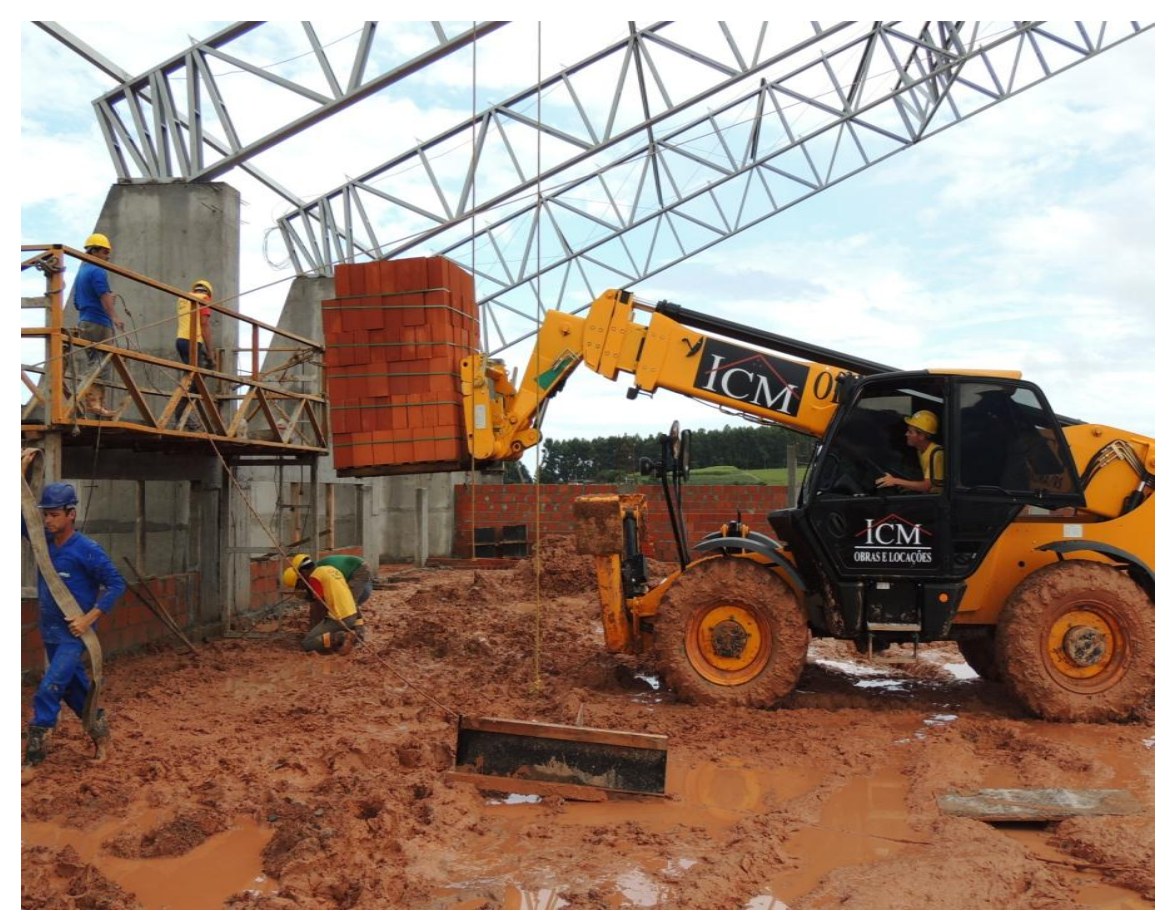

Figura 28

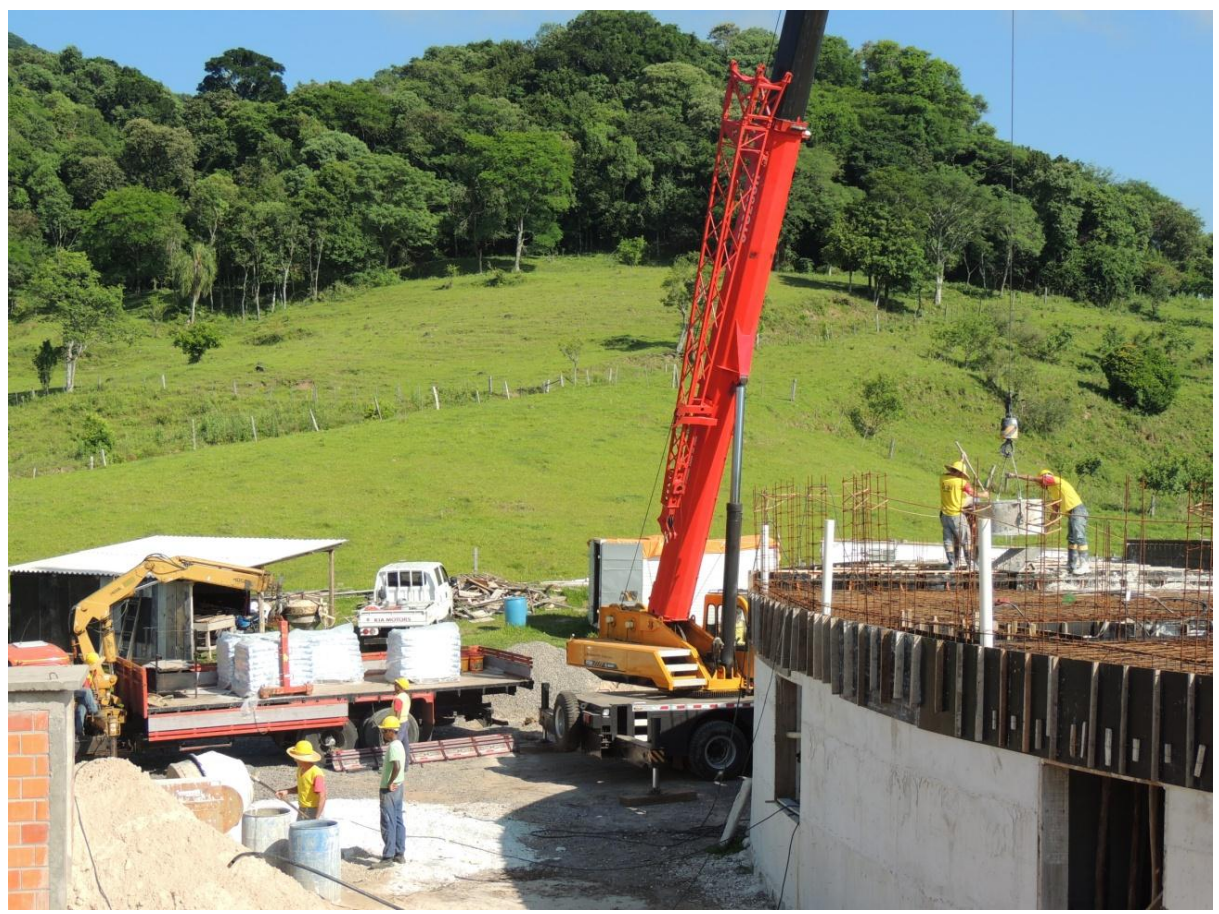

Figura 29 


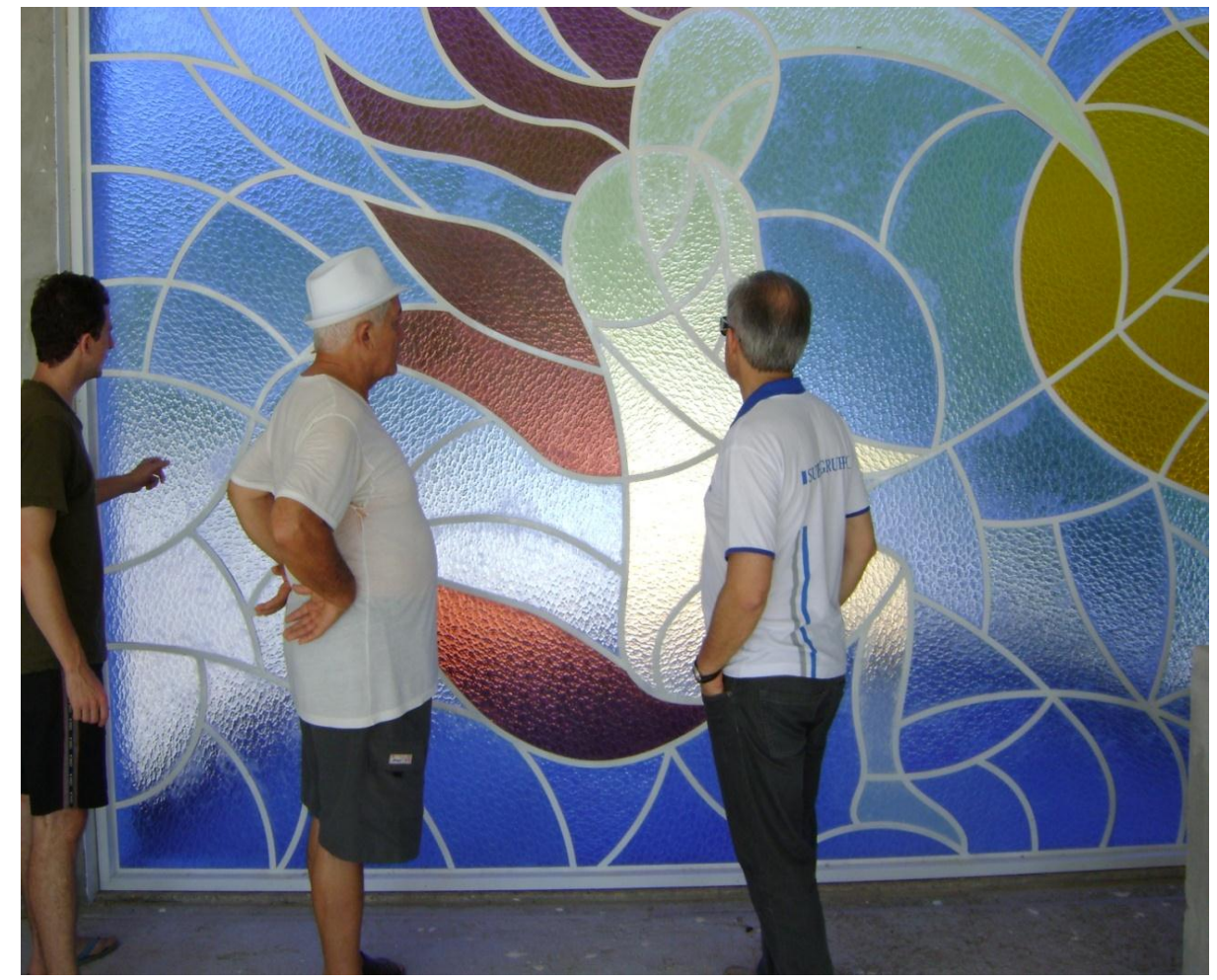

Figura 30

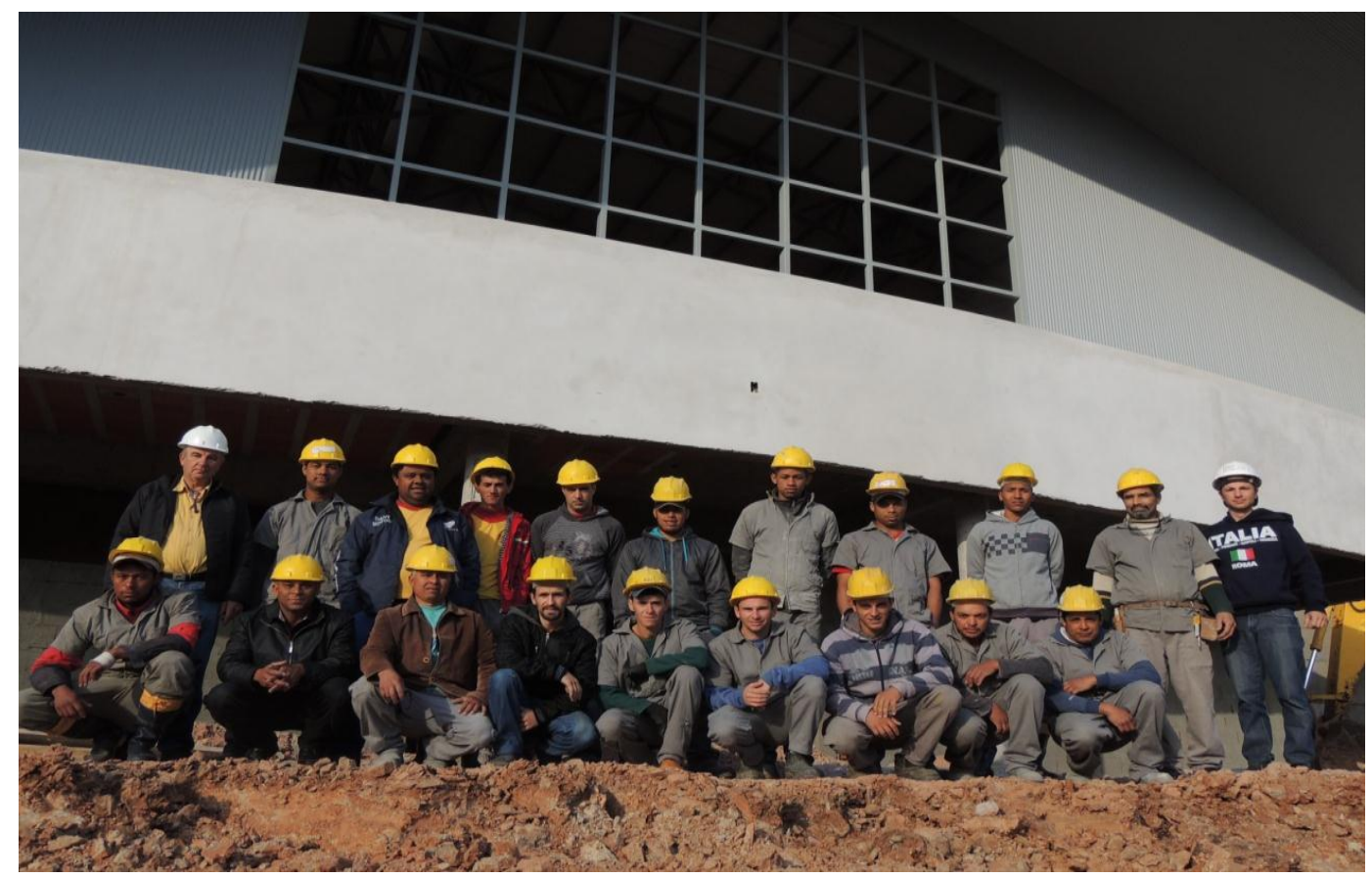

Figura 31 